\title{
Purification and identification of a polysaccharide from medicinal mushroom Amauroderma rude with immunomodulatory activity and inhibitory effect on tumor growth
}

\author{
Honghui Pan'1, Yuanyuan Han ${ }^{1}$, Jiguo Huang1, Xiongtao Yu1, Chunwei Jiao², \\ Xiaobing Yang ${ }^{1}$, Preet Dhaliwal ${ }^{3,4}$, Yizhen Xie ${ }^{1}$, Burton B. Yang ${ }^{3,4}$ \\ ${ }^{1}$ Guangdong Institute of Microbiology, State Key Laboratory of Applied Microbiology Southern China, Guangdong Provincial \\ Key Laboratory of Microbial Culture Collection and Application, Guangdong Open Laboratory of Applied Microbiology, \\ Guangzhou, China \\ ${ }^{2}$ Yuewei Edible Fungi Technology Co. Ltd., Guangzhou, China \\ ${ }^{3}$ Sunnybrook Research Institute, Sunnybrook Health Sciences Centre, Toronto, Canada \\ ${ }^{4}$ Department of Laboratory Medicine and Pathobiology, University of Toronto, Toronto, Canada \\ Correspondence to: \\ Yizhen Xie, e-mail: 13622216490@126.com \\ Burton B. Yang, e-mail: byang@sri.utoronto.ca \\ Keywords: medicinal mushroom, herbal medicine, tumor growth, cytokine, amauroderma \\ Received: April 28, 2015 \\ Accepted: June 15, 2015 \\ Published: June 27, 2015
}

\section{ABSTRACT}

Medicinal mushrooms in recent years have been the subject of many experiments searching for anticancer properties. We previously screened thirteen mushrooms for their potential in inhibiting tumor growth, and found that the water extract of Amauroderma rude exerted the highest activity. Previous studies have shown that the polysaccharides contained in the water extract were responsible for the anticancer properties. This study was designed to explore the potential effects of the polysaccharides on immune regulation and tumor growth. Using the crude Amauroderma rude extract, in vitro experiments showed that the capacities of spleen lymphocytes, macrophages, and natural killer cells were all increased. In vivo experiments showed that the extract increased macrophage metabolism, lymphocyte proliferation, and antibody production. In addition, the partially purified product stimulated the secretion of cytokines in vitro, and in vivo. Overall, the extract decreased tumor growth rates. Lastly, the active compound was purified and identified as polysaccharide F212. Most importantly, the purified polysaccharide had the highest activity in increasing lymphocyte proliferation. In summary, this molecule may serve as a lead compound for drug development.

\section{INTRODUCTION}

As a great source of polysaccharides, medicinal mushrooms are commonly used herbs in oriental countries for treatment of various diseases. A variety of pharmaceutical properties of polysaccharides have been revealed including antioxidant [1], anti-inflammatory [2], antiallergic [3], antitumor [4-6], antidiabetes [7], anticoagulant [8], antiviral [9], immunomodulatory [10], antihepatopathy [11], and antifatigue [12]. The polysaccharides contained in some mushrooms have been shown to have immonopotentiating effects on many cells in the immune system, including T cells, B cells, and macrophages [13]. For example, Polysaccharide
Krestin (PSK) and Polysaccharide Peptide (PSP), isolated from Coriolus versicolor, have been subject to clinical trials, and shown to have positive effects against cancer, and they have been used in clinical settings for several decades $[14,15]$. Furthermore, the extraction and use of polysaccharides from many other mushrooms such as Ganoderma lucidum [16] Lentinula edodes [17], Agaricus blazei [18], Antrodia camphorate [19], and Grifola frondosaI [20] have also been shown to stimulate immune activity. This caused us to look further into another mushroom, Amauroderma rude.

Amauroderma rude (Berk.) Torrend belongs to the Ganodermataceae family and distributes in the tropical and subtropical zone [21]. We have previously demonstrated 
that the water extract of Amauroderma rude can inhibit cancer cell growth [6]. Since polysaccharides may be the major components in the water extract, we hypothesized that the polysaccharides of Amauroderma rude may have immune regulatory activity. This study was designed to explore the potential effects of the polysaccharides isolated from Amauroderma rude on stimulating immune activity and tumor growth inhibition.

\section{RESULTS}

\section{Amauroderma rude extract increased the immunomodulatory activity in vitro}

We examined the possible immunomodulatory activity of the crude polysaccharides from the water extract of Amauroderma rude (AR). Mouse lymphocytes were isolated from the spleen and their proliferation was tested in the presence of the water extract, along with endotoxins, lipopolysaccharides (LPS), and Concanavalin A (ConA), since proliferation of spleen lymphocytes is the prime indicant of immunopotentiation [13]. We found that AR extract was the most effective agent in stimulating proliferation of the lymphocytes (Figure 1a and 1b). AR alone or acting together with LPS/ConA significantly increased lymphocyte proliferation in a dose-dependent manner compared with the control group.

We also isolated macrophages from mouse peritoneal cavity and incubated them with AR, since macrophages exert a variety of complex microbicidal functions [22]. We found that incubation with AR improved energy metabolism of macrophages (Figure 1c) and increased macrophage engulfing of neutral red (Figure 1d). Incubation of macrophages with AR also increased production of nitric oxide in a dosedependent manner compared with the control group (Figure 2a). Natural killer (NK) cells are important effectors in innate immunity, but also play a role in the regulation of the adaptive immune response [23]. We found that incubation with AR increased the function of mouse natural killer cells significantly, by destroying more cancer cells (Figure 2b). CD45 is a cell surface glycoprotein that has been implicated in the integrinmediated adhesion of macrophages, and is reported to affect the functional responsiveness of cells to chemo-attractants [24]. We found that incubation with AR increased the percentage of CD45 significantly, compared with the control group (Figure 2c).

\section{Amauroderma rude extract increased immunomodulatory activity in vivo}

We explored the immunomodulatory activity of Amauroderma rude in normal mice that maintain a normal immune system. The effect of AR on the spleen and thymus was examined by evaluating the spleen index and thymus index of five groups. We found that the spleen index of mice treated with AR extract increased significantly compared to the control group, while the thymus index was not affected (Figure 3a).

We then examined the immunomodulatory activity of AR in cellular immune function, humoral immunity, and mononuclear macrophage function. The spleen lymphocyte proliferated faster in all groups treated with AR extract, although not to the levels of LPS treatment, compared with the negative control group (Figure $3 b$ ). The weight of earlaps increased significantly in the mice treated with AR extract and LPS (Figure 3c).

Mononuclear macrophages were isolated from mice injected with AR extract and LPS. Their function was assessed using the carbon clearance test and engulfment of fluorescent microspheres. We evaluated the phagocytic index of AR groups and found significant increase with all doses of AR extract in the carbon clearance test, compared to the negative control group (Figure $3 \mathrm{~d}$ ). The fluorescent microsphere index reached significant levels only when the AR doses were relatively high (Figure 3d).

In the humoral immunity assay, we detected a significant increase in the aggregation of antibodies (Figure 3e, left), and the formation of hemolysis plaques (Figure 3e, right), when the mice were treated with AR extract or LPS. In the energy metabolism assay, we detected significant increase in the proliferation of macrophages isolated from mice injected with AR extract (Figure 3f).

We tested the immunoreactivity of the partially purified polysaccharides in vivo. After tumor cell implantation, the mice were orally given the polysaccharide fraction with the highest activity in lymphocyte proliferation (Fraction $\mathrm{F}_{0.5}, 2.4 \mathrm{mg} / \mathrm{mouse}$ ). $7 \mathrm{~h}$ after delivery, we detected significant increase in the secretion of IL-2 (Figure 4a, left) and IFN- $\gamma$ (Figure 4a, right) compared with the control. These results were further confirmed by in vitro assays, where the partially purified $\mathrm{F}_{0.5}$ Fraction was applied to mouse spleen lymphocytes. $24 \mathrm{~h}$ after the addition of the polysaccharides, we detected significant increase in the secretion of IL-2 (Figure 4b) and TNF- $\alpha$ (Figure 4c) in a dose-dependent manner, compared to the control.

\section{Amauroderma rude extract inhibited tumor growth in mice}

We then explored whether injection of the AR extract affected tumor growth. After tumor implantation, the mice were injected with AR extract and the tumor growth rates were monitored every three days. We detected a significant decrease in tumor growth rates starting on day 20 in both groups, which were injected with two doses of AR extract (Figure 5a, upper for tumor growth rates, lower for a photo of typical tumor sizes). When the animal experiment finished, the tumors were 
a

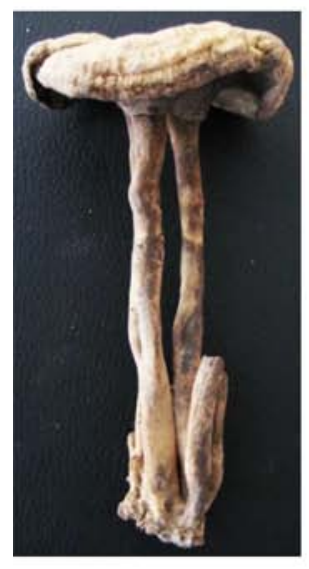

Dry Amauroderma rude

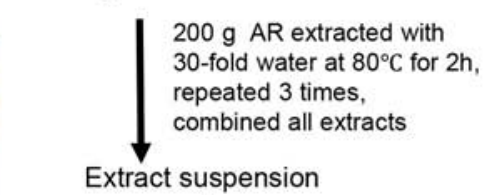

supernatant pellet (discarded)

Concentrated by rotary evaporation to 1 liter

supernatant

Precipitated with 3 vol $95 \%$ ethanol overnight to get pellet by centrifugation at $6000 \mathrm{rpm}$ for $30 \mathrm{~min}$

Crude polysaccharide fraction (re-dissolved in water to test its activity)
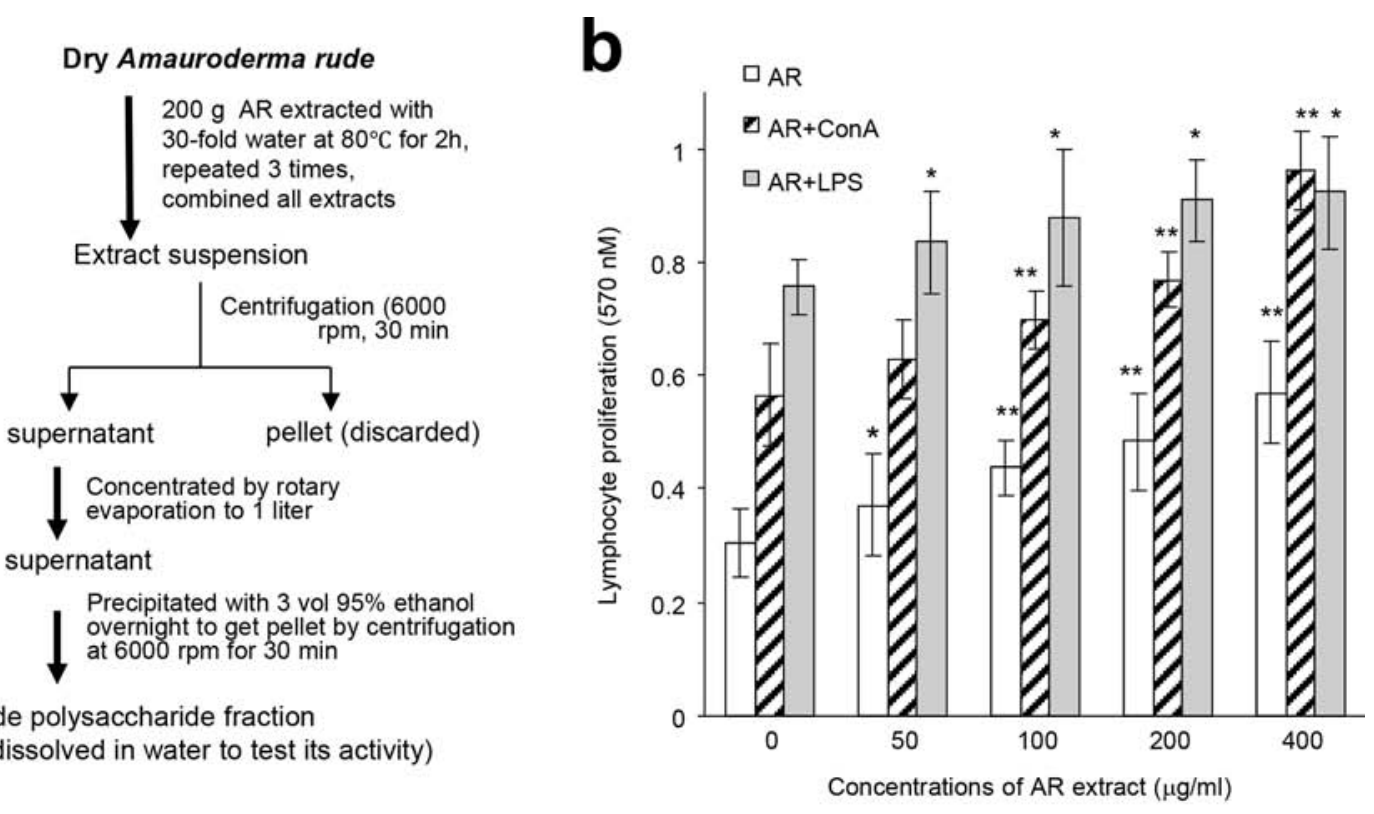

d

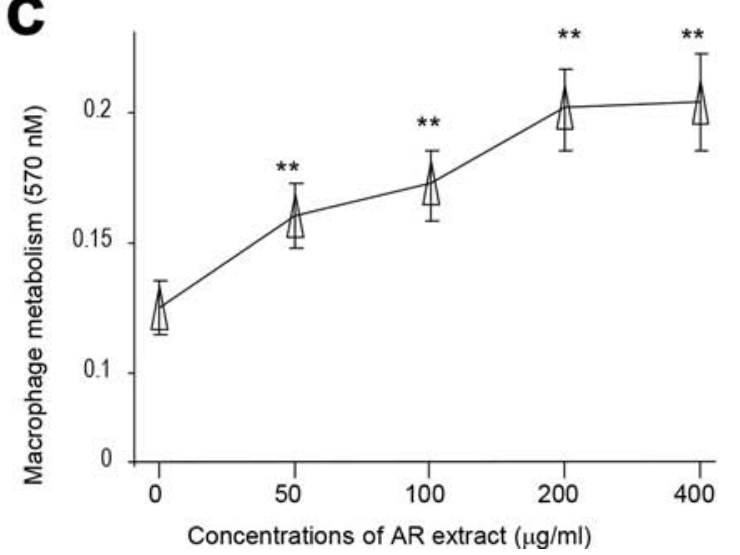

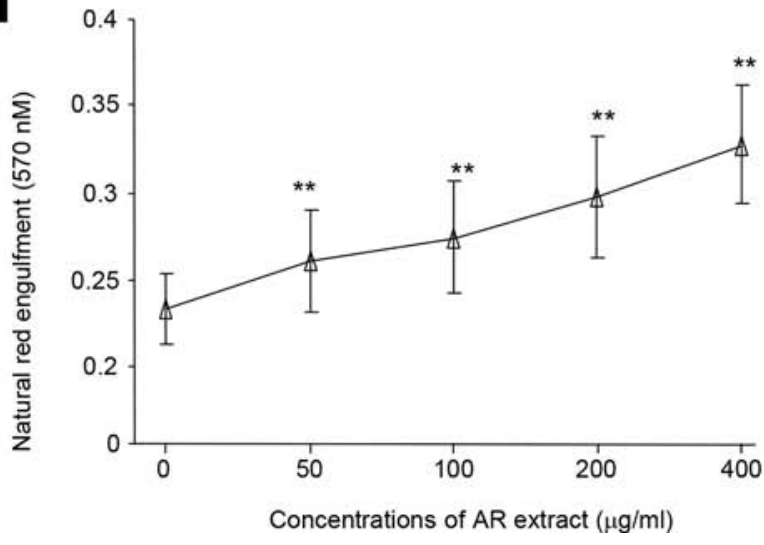

Figure 1: Effects of AR on cellular activities of mouse spleen lymphocytes and macrophages. a. Procedure for preparation of water extract from Amauroderma rude. b. Mouse spleen lymphocytes were incubated with AR extract at $37^{\circ} \mathrm{C}$ for $44 \mathrm{~h}$, followed by MTT assay. Incubation with AR extract increased lymphocyte proliferation. Inclusion of ConA and LPS displayed additive effect on enhancing lymphocyte proliferation. Asterisks indicate significant differences. ${ }^{*} p<0.05, * * p<0.01$. Error bars, $\mathrm{SD}(n=5)$. All experiments were repeated three times. c. In energy metabolism assay, mouse macrophages were incubated at $37^{\circ} \mathrm{C}$ for $2 \mathrm{~h}$, followed by addition of drugs or AR extract. The cultures were then incubated at $37^{\circ} \mathrm{C}$ for $20 \mathrm{~h}$ followed by MTT assays. Treatment with AR extract improved energy metabolism. Asterisks indicate significant differences. ${ }^{* *} p<0.01$. Error bars, SD $(n=5)$. d. In the neutral red engulfment assay, cells in the $96-w e l l$ plates were incubated at $37^{\circ} \mathrm{C}$ for $24 \mathrm{~h}$. After centrifugation $(1800 \mathrm{rpm}, 5 \mathrm{~min}), 100 \mu \mathrm{l}$ of neutral red in physiological saline solution $(0.1 \%)$ were added to each well. The plates were incubated at $37^{\circ} \mathrm{C}$ for $30 \mathrm{~min}$. After centrifugation $(1800 \mathrm{rpm}, 5 \mathrm{~min})$, each well was washed with $200 \mu \mathrm{l}$ PBS twice, followed by addition of $100 \mu \mathrm{l}$ cytolysate (acetic acid:anhydrous alcohol $=50: 50$ ). The cells were incubated at room temperature overnight followed by MTT assay. Incubation with AR extract increased engulfment of neutral red by the cells. Asterisks indicate significant differences. $* * p<0.01$. Error bars, $\mathrm{SD}(n=5)$.

excised and weighed. The weight of tumors decreased significantly in both groups of mice that were injected with AR extract (Figure $5 b$ ). The average body weight of the mice injected with AR extract was higher compared to the control (Figure 5c). This suggests improved quality of life.

Tumor sections were subject to H\&E staining and examined under a light microscope. We found that the AR extract induced extensive tumor cell death (Figure 5d). We also examined the proliferative capacity of the tumor cells using Ki67 positive cells. Injection of AR extract in the tumor implanted mice significantly decreased Ki67 positive cells, which suggested decreased proliferative activity (Figure 5e). Furthermore, CD34 staining also displayed decreased levels of positive cells in these mice (Figure 5e). 

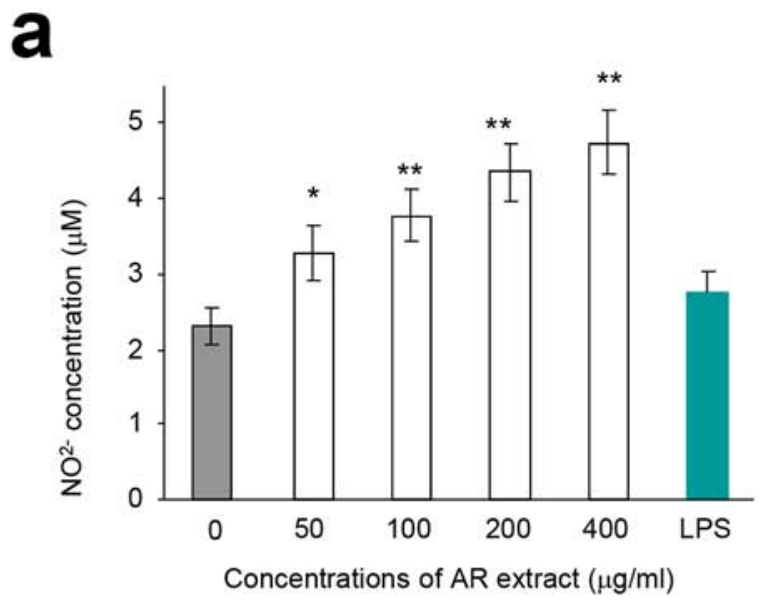

b

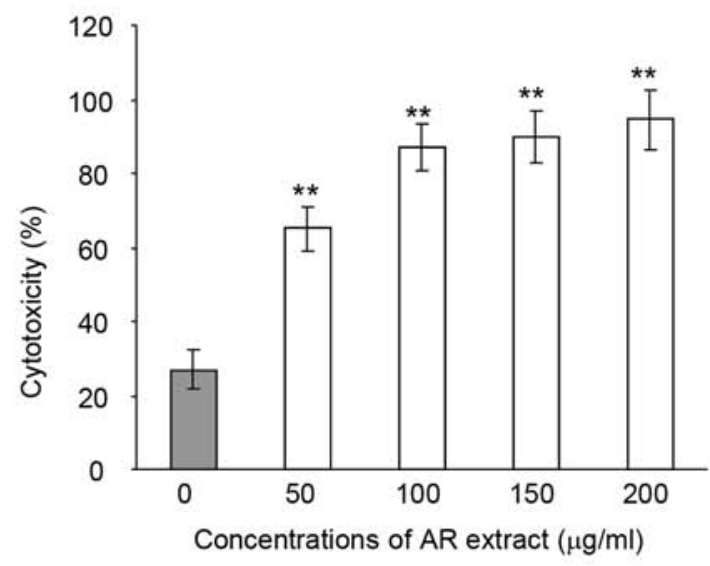

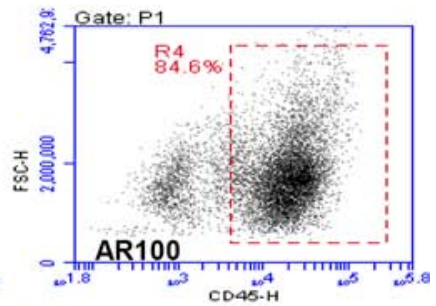

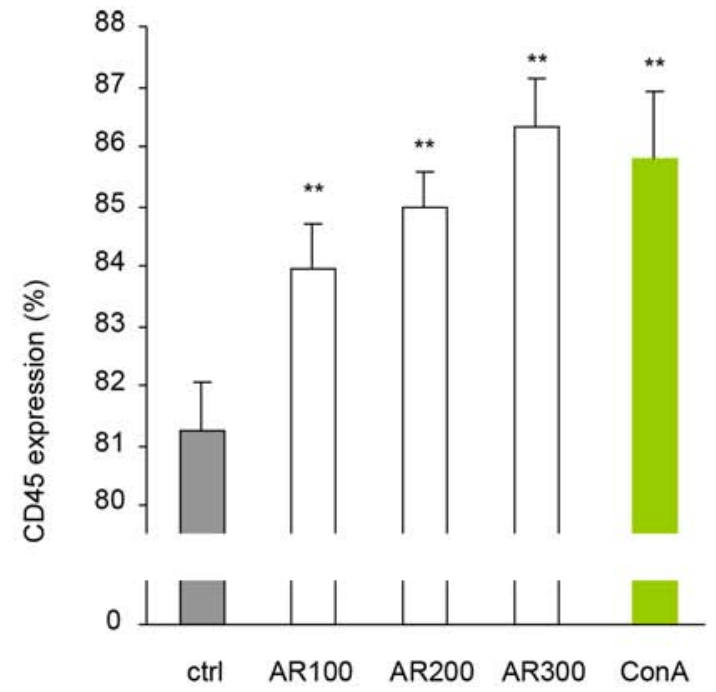

Concentrations of AR extract $(\mu \mathrm{g} / \mathrm{ml})$
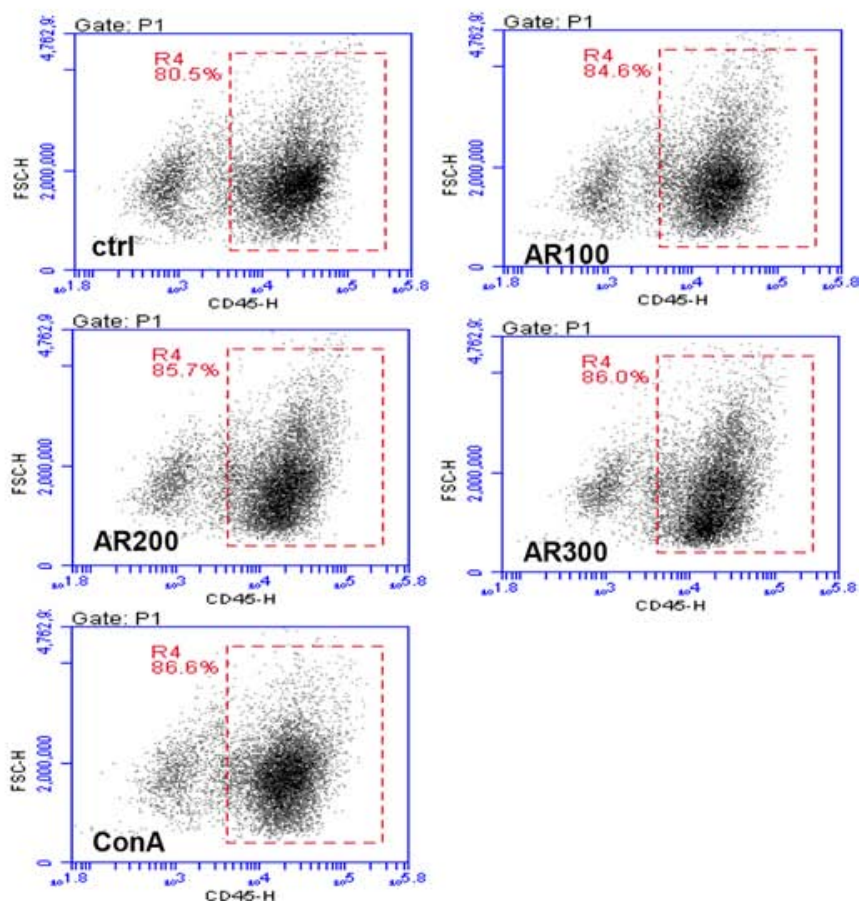

Figure 2: Effects of AR on macrophages and natural killer cells. a. Mouse macrophages were incubated at $37^{\circ} \mathrm{C}$ for $2 \mathrm{~h}$. Drugs and samples were added to the cultures at the concentrations indicated. The cultures were incubated at $37^{\circ} \mathrm{C}$ for $48 \mathrm{~h}$ followed by Griess assay to measure nitric oxide concentrations. Incubation with AR extract increased the production of nitric oxide by macrophages. Asterisks indicate significant differences. ${ }^{*} p<0.05,{ }^{* *} p<0.01$. Error bars, SD $(n=5)$. All experiments were repeated three times. b. In NK cell assay, the harvested lymphocytes were incubated at $37^{\circ} \mathrm{C}$ for $2 \mathrm{~h}$ followed by treatment with AR extract. The effect of NK cells was assayed as described in the Methods. Incubation with AR extract stimulated and increased the activity of NK cells in killing breast cancer cells. Asterisks indicate significant differences. ${ }^{*} p<0.05,{ }^{*} p<0.01$. Error bars, SD $(n=5)$. c. Lymphocytes were inoculated and incubated at $37^{\circ} \mathrm{C}$ for $2 \mathrm{~h}$, followed by addition of drugs and samples. The cultures were then incubated at $37^{\circ} \mathrm{C}$ for $48 \mathrm{~h}$ before flow cytometry analysis for CD45 expression. Incubation with AR extract increased CD45 expression. Asterisks indicate significant differences. $* p<0.05$, $* * p<0.01$. Error bars, SD $(n=5)$. Right, typical measurements of CD45 levels by flow cytometry.

\section{The partially purified Amauroderma rude extract activated mouse immune activity and inhibited tumor growth}

To understand the components that played a role in the modulation of immune activity and inhibition of tumor growth, we purified the AR extract using column fractionation (Figure 6a). The effects of different fractions of the partially purified polysaccharides were tested by lymphocyte proliferation. Mouse spleen lymphocytes were used, alongside LPS as the positive control. The experiment showed that the $\mathrm{F}_{0.5}$ was the most effective 
a

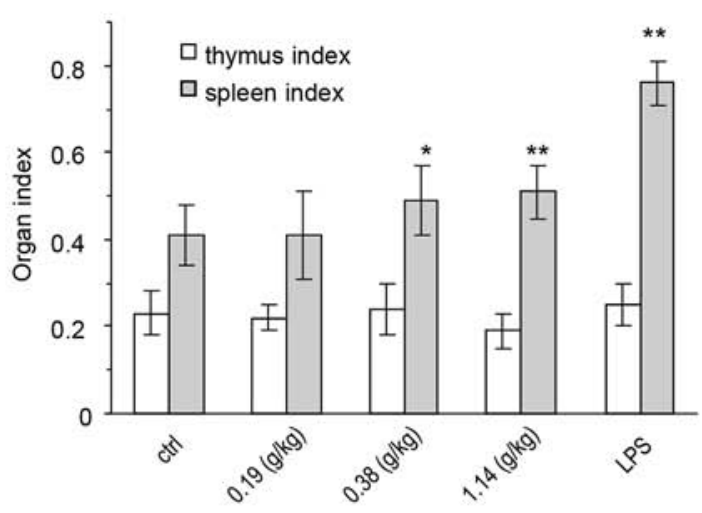

C

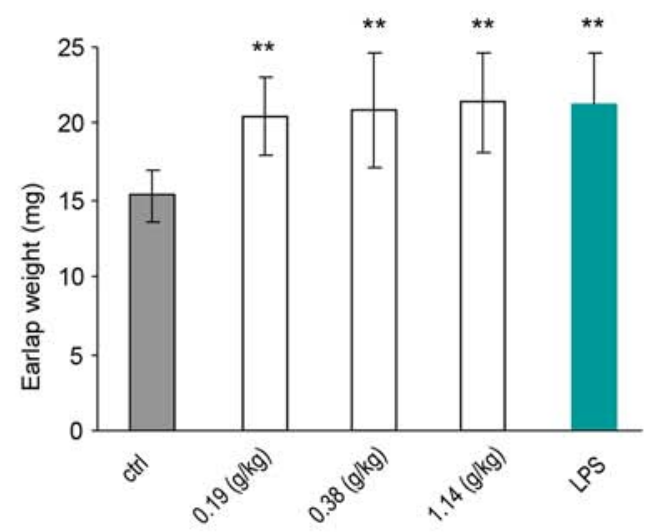

b

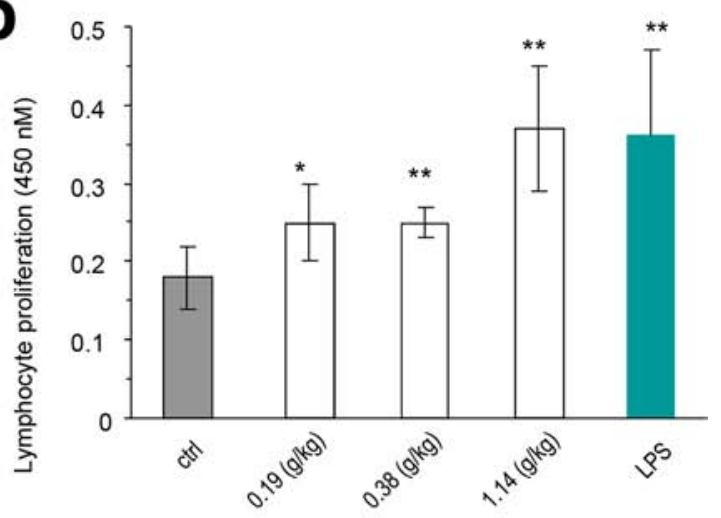

d

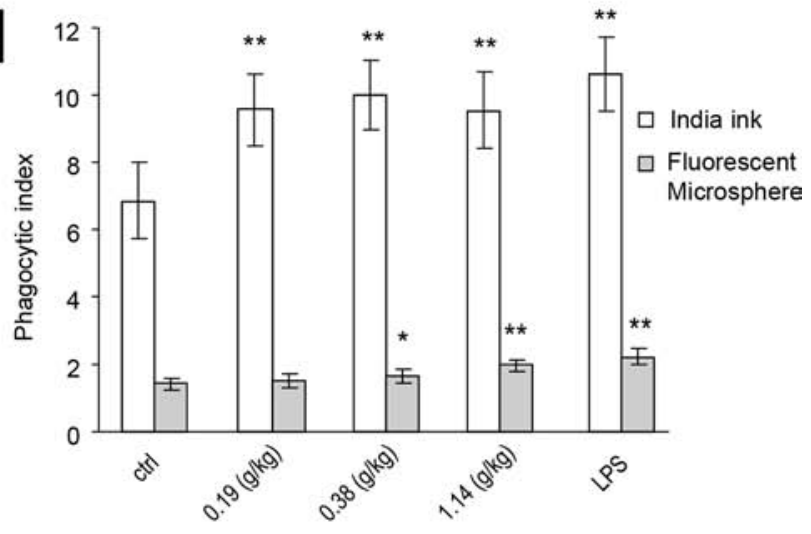

e

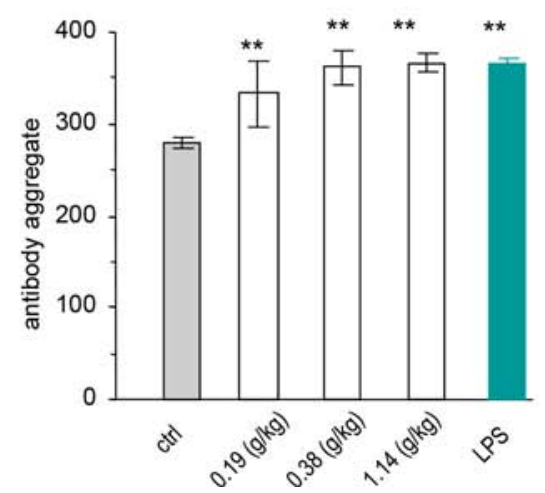

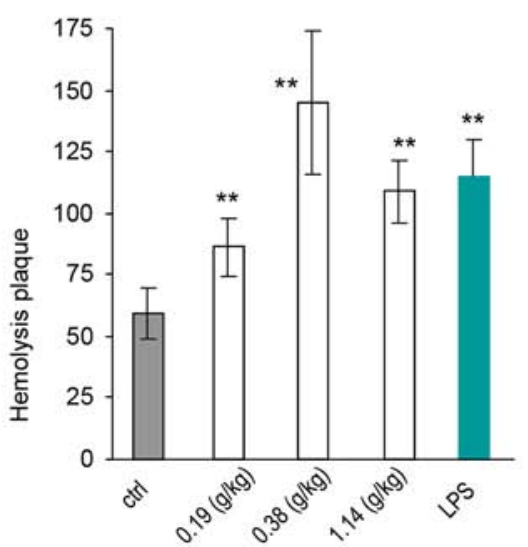

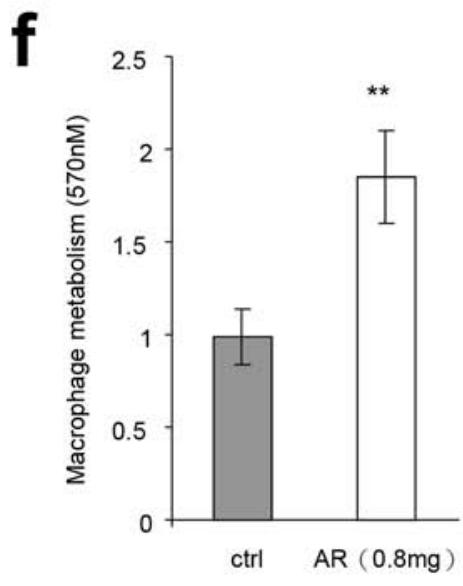

Figure 3: The immunomodulatory activity of Amauroderma rude in normal animals. a. The in vivo experiments were described in detail in the Methods. Injection of normal mice with AR extract increased sizes of spleens, but had little effect on thymus. Similarly, injection with LPS only increased the size of spleen but not the thymus. Asterisks indicate significant differences. ${ }^{*} p<0.05$, $* * p<0.01$. Error bars, $\mathrm{SD}(n=5)$. All experiments were repeated three times. b. Injection of mice with AR extract increased the proliferation rates of the spleen lymphocytes. Asterisks indicate significant differences. ${ }^{*} p<0.05,{ }^{* *} p<0.01$. Error bars, SD $(n=5)$. c. Mice injected with AR extract displayed increased weight of the earlaps. Asterisks indicate significant differences. ${ }^{*} p<0.05,{ }^{* *} p<0.01$. Error bars, $\mathrm{SD}(n=5)$. d. Engulfment of Fluorescent Microspheres and Indian ink by the cells was increased by treatment with AR extract. Asterisks indicate significant differences. ${ }^{*} p<0.05,{ }^{* *} p<0.01$. Error bars, $\mathrm{SD}(n=5)$. e. Antiserum isolated from mice injected with AR extract displayed hemolysis plaques (left) and antibody aggregation in the agglutination assay (right). Asterisks indicate significant differences. ${ }^{*} p<0.05, * * p<0.01$. Error bars, $\mathrm{SD}(n=5)$. f. Injection of mice with AR extract increased energy metabolism of macrophages. Asterisks indicate significant differences. ${ }^{*} p<0.05, * * p<0.01$. Error bars, $\mathrm{SD}(n=5)$. 
a

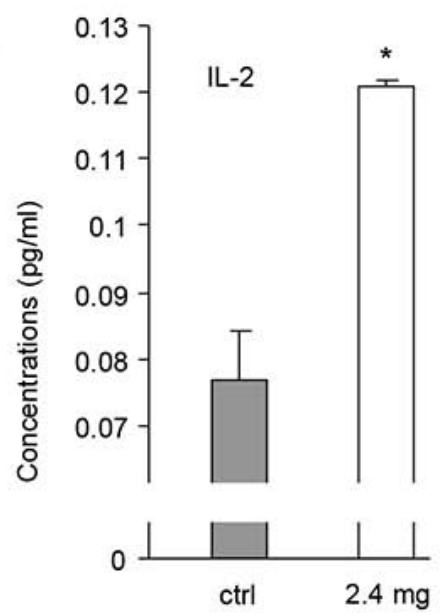

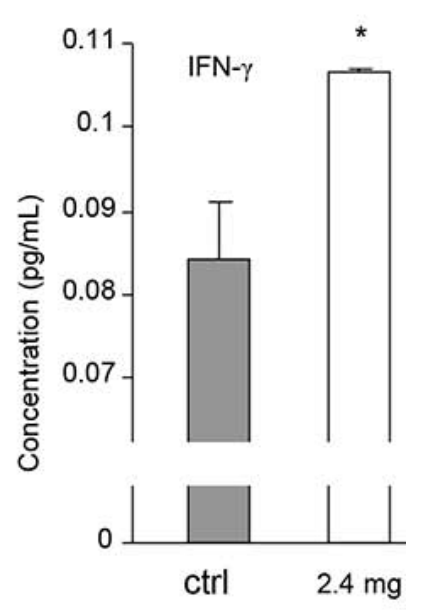

b

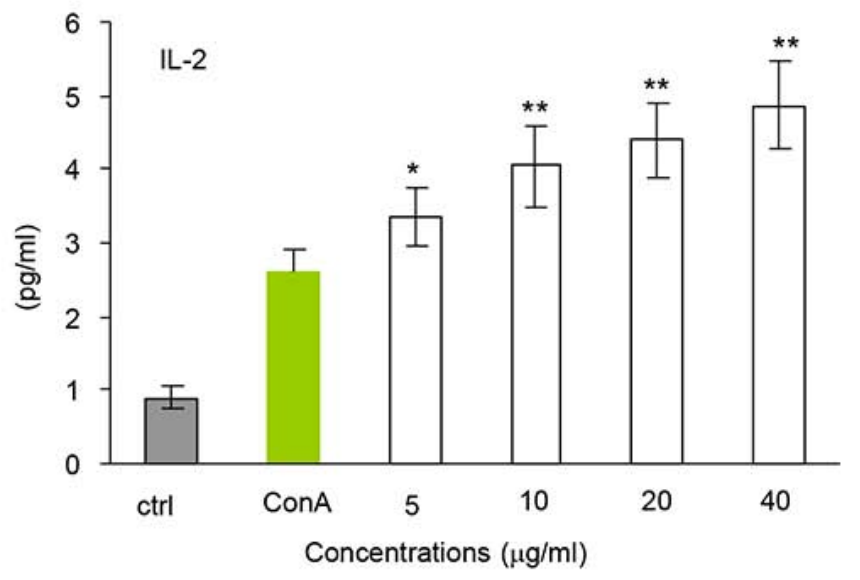

C

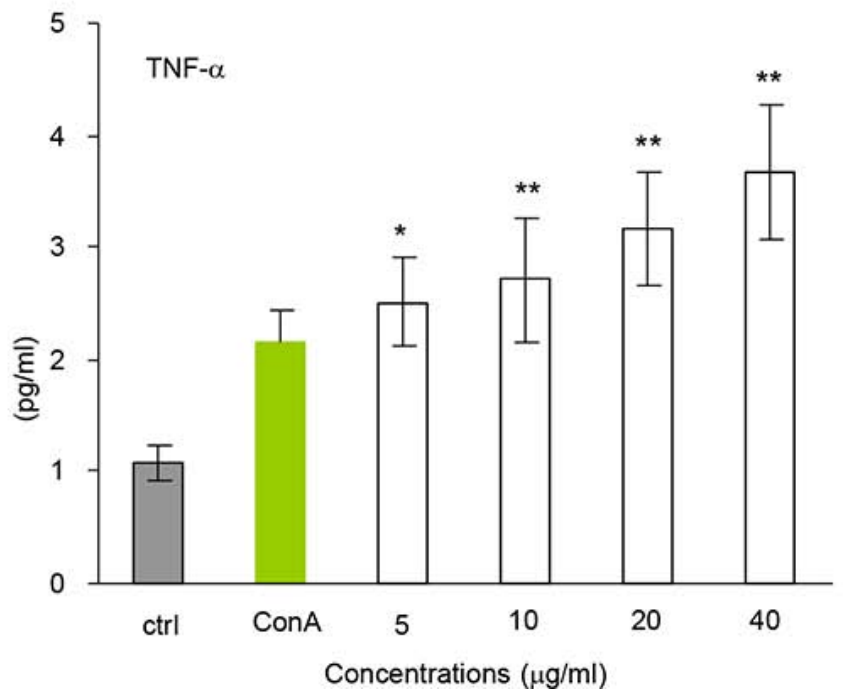

Figure 4: AR induced cytokine expression. a. After tumor cell implantation, the mice were orally given AR extract (2.4 $\mathrm{mg} / \mathrm{mouse})$. $7 \mathrm{~h}$ later, the levels of secreted IL-2 (left) and IFN- $\gamma$ (right) were measured. Asterisks indicate significant differences. ${ }^{*} p<0.05$, Error bars, $\mathrm{SD}(n=5)$. All experiments were repeated three times. b-c. AR extract was applied to the cultures of mouse spleen lymphocytes in the concentrations indicated. $24 \mathrm{~h}$ later, the levels of secreted IL-2 (b) and TNF- $\alpha$ (c) were measured. Asterisks indicate significant differences. ${ }^{*} p<0.05,{ }^{* *} p<0.01$. Error bars, $\mathrm{SD}(n=5)$. 


\section{a}
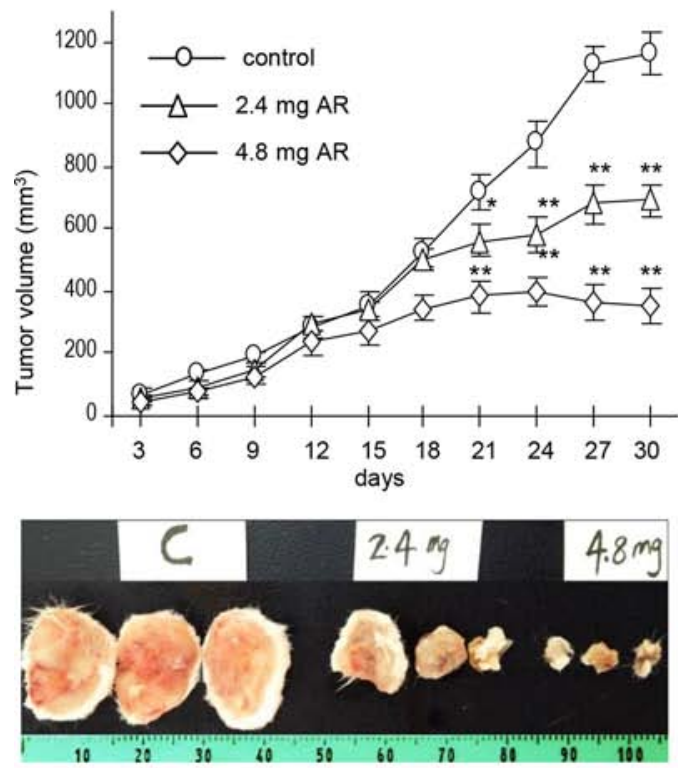

b

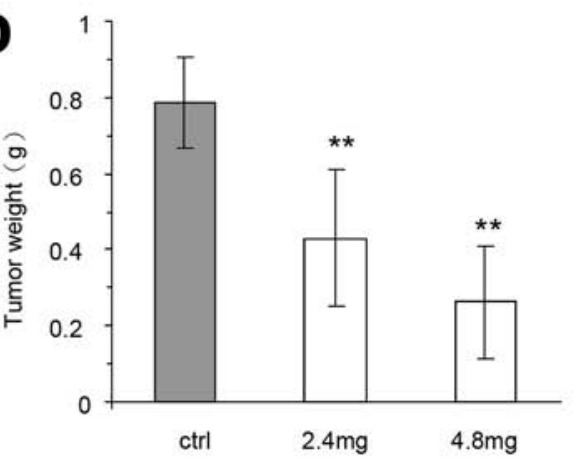

C

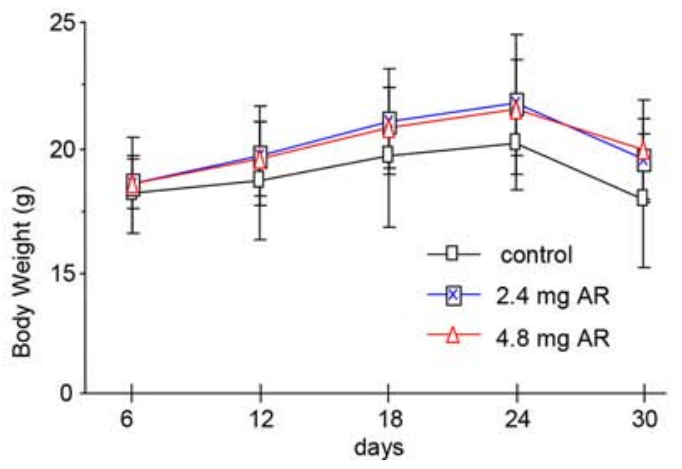

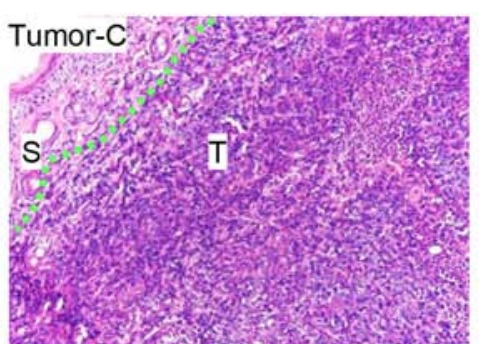
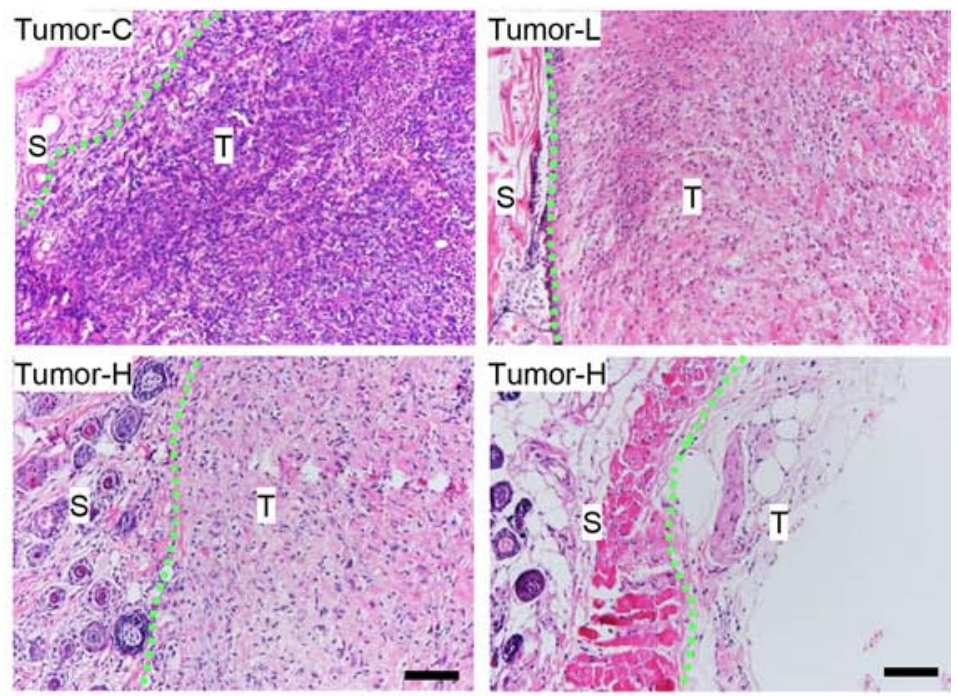

e
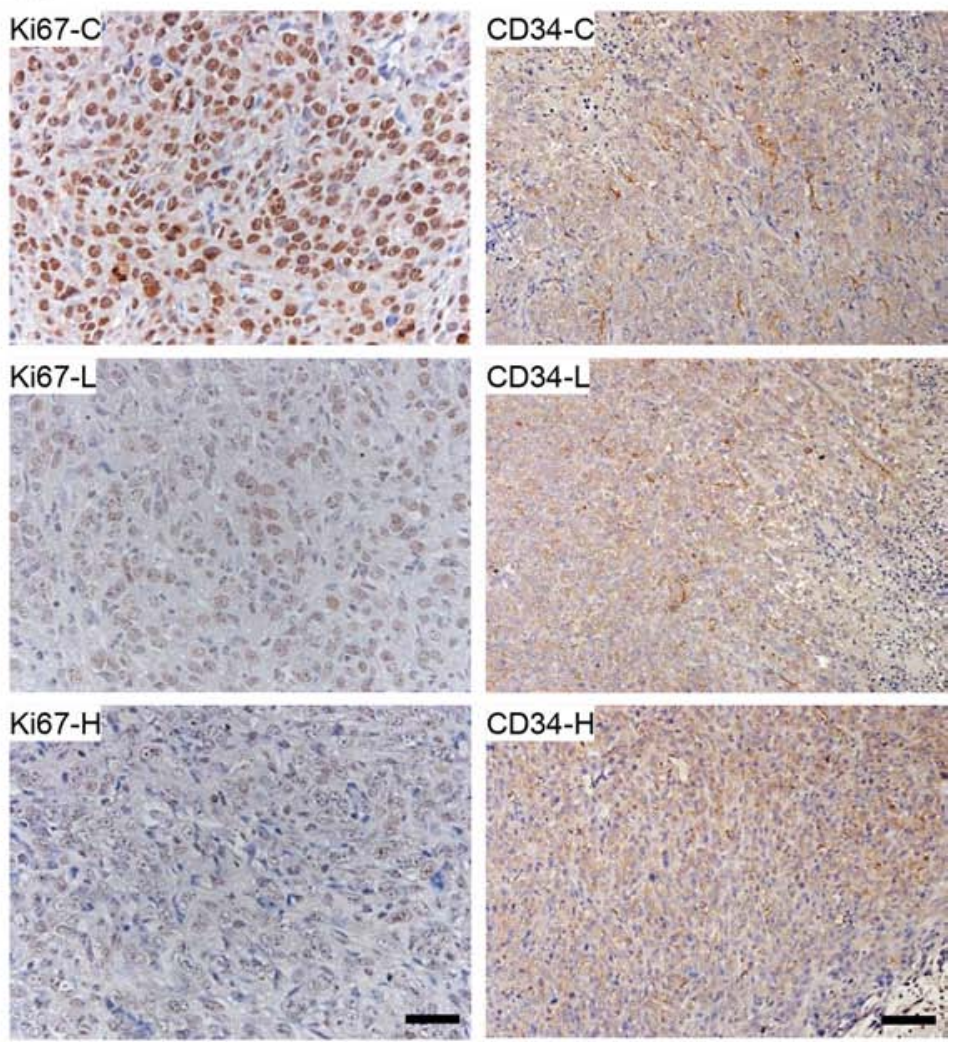

Figure 5: AR inhibited tumor growth by inducing tumor cell death and inhibiting Ki67 and CD34 expression. a-b. After tumor cell implantation, the mice were injected with AR extract and monitored for tumor growth. Injection with AR extract inhibited tumor growth by decreasing tumor volumes (a, upper, tumor growth curve, lower, typical photo of tumor sizes) and decreased tumor weight (b). Greater dose of AR extract displayed stronger inhibitory effect on tumor growth. Asterisks indicate significant differences. ${ }^{*} p<0.05$, $*^{*} p<0.01$. Error bars, SD $(n=12$ mice). All experiments were repeated three times. c. The injection of AR had little effect on the body weight of the mice. d. Tumor sections were subject to H\&E staining and examined under a light microscope. Extensive cell death was detected in mice injected with both doses of polysaccharides. Tumor-C, control group; Tumor-L, low dose group; Tumor-H, high dose group; S, stromal tissue; T, tumor; Scale bars, $50 \mu \mathrm{m}$. e. Tumor sections (control, low dose, and high dose) were subject to Ki67 and CD34 staining followed by examination and photograph under a light microscope. Tumors formed in the mice injected with the polysaccharides, and displayed a decreased number of Ki67 positive cells and CD34 positive cells. Scale bars, $50 \mu \mathrm{m}$. 


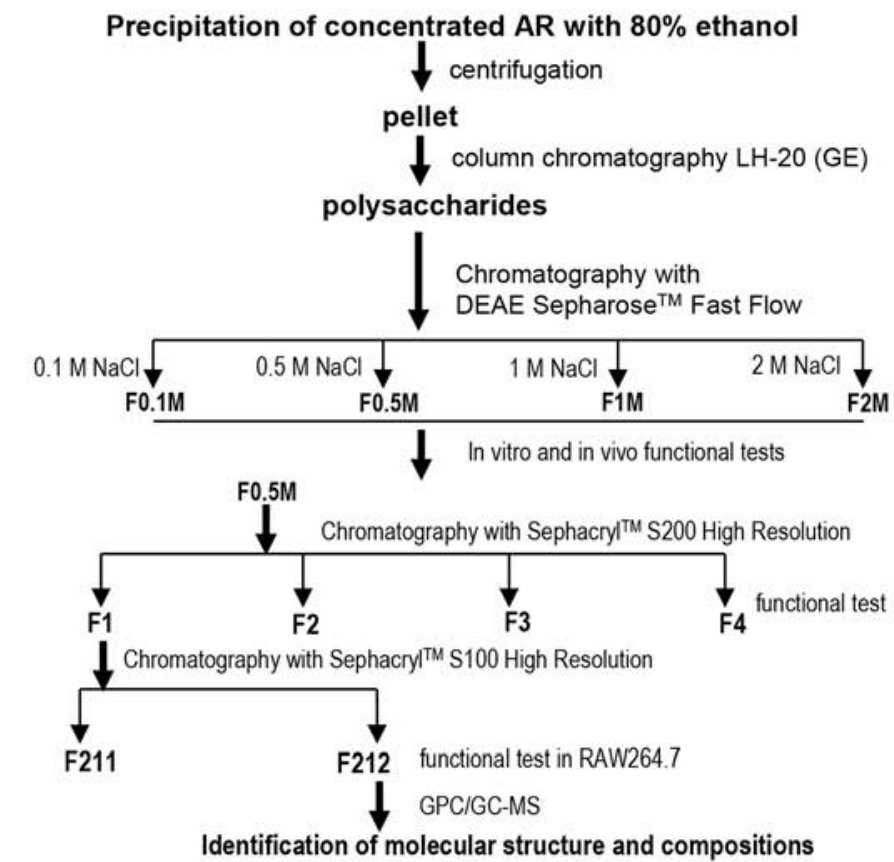

C

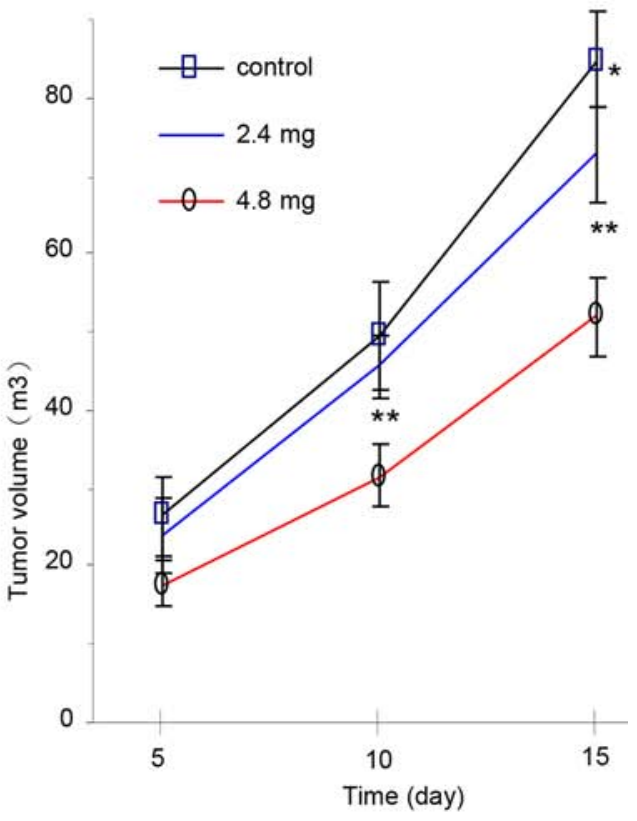

\section{b}

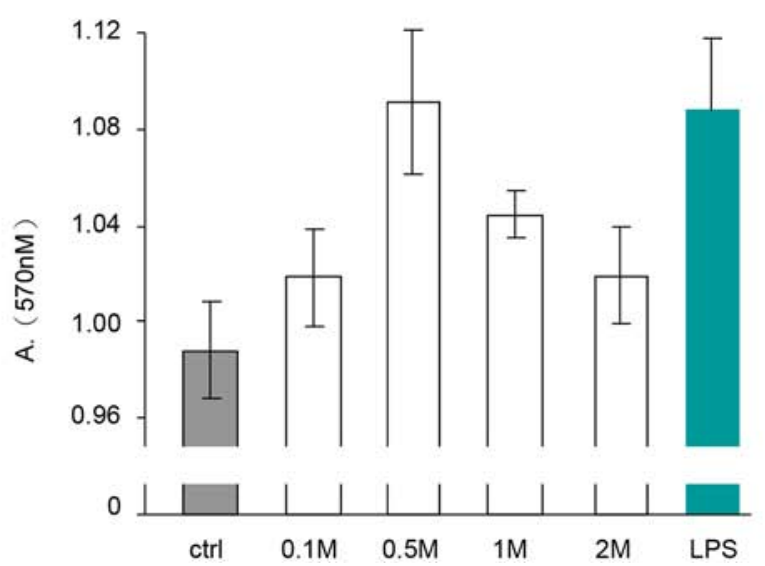

d

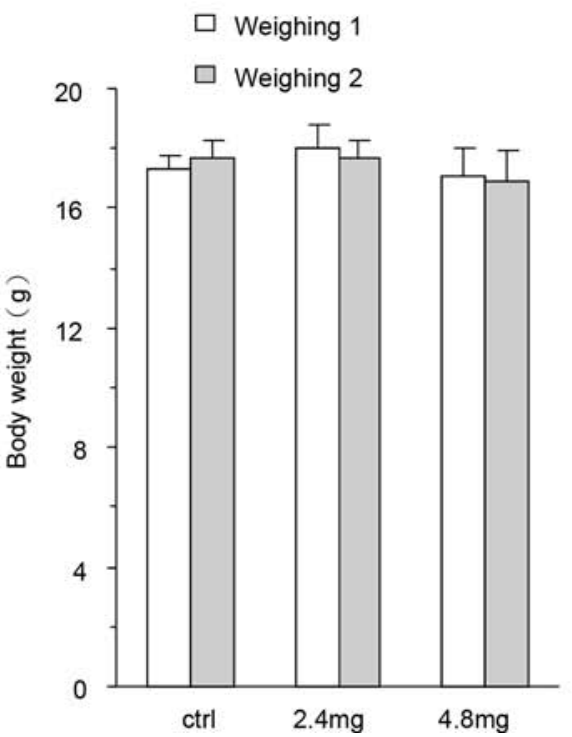

Figure 6: Partial purification of the polysaccharides and their effects on lymphocyte activity and tumorgrowth. a. Procedure for purification of polysaccharides from the water extract of Amauroderma rude. b. The effect of four different components purified from AR extract on the proliferation of mouse spleen lymphocytes. It appeared that the fraction eluted with $0.5 \mathrm{M}\left(\mathrm{F}_{0.5}\right) \mathrm{NaCl}$ displayed the strongest effect on increasing lymphocyte proliferation. c. After tumor cell implantation, the mice were injected with the partially purified polysaccharides $\mathrm{F}_{0.5}$ at different time points as indicated in the Methods section, and monitored for tumor growth. Injection with $\mathrm{F}_{0.5}$ inhibited tumor growth in both doses used. Asterisks indicate significant differences. ${ }^{*} p<0.05, * * p<0.01$. Error bars, SD ( $n=12$ mice). d. The body weight of the mice was not affected by tumor cell implantation or by polysaccharide injection.

fraction among the four fractions tested. It increased lymphocyte proliferation to a level similar to LPS (Figure 6b).

The effect of the partially purified polysaccharides on tumor growth was tested. We delivered the $\mathrm{F}_{0.5}$ fraction into mice that had been implanted with tumor cells. $\mathrm{F}_{0.5}$ inhibited tumor growth significantly (Figure $6 \mathrm{c}$ ), but had no effect on the size of the mice (Figure 6d). These results suggest that the polysaccharides of Amauroderma rude exerted two layers of effects on tumor growth in vivo: it inhibited tumor cell proliferation and it increased tumor cell death.

\section{The purified Amauroderma rude polysaccharide promoted mouse immune activity}

We further purified the fraction $\mathrm{F}_{0.5}$ by chromatography using column Sephacryl ${ }^{\text {TM }}$ S200 High 
Resolution. Four fractions were obtained (Figure 6a, F1, F2, F3, and F4). We identified that F1 possessed the highest activity in functional tests. This fraction was further purified by chromatography using column Sephacryl ${ }^{\text {TM }}$ S100 High Resolution. One typical peak of polysaccharides was detected (Figure 7a, labeled 14.774). After functional testing, we detected major activity in the peak of F212. We identified the monosaccharide compositions of F212 by contrasting monosaccharides with reference substances and using the Total Ion Chromatogram (TIC) (Figure 7b). Data analysis indicated that F212 was made up of Ribose, Rhamnose, Arabinose, Xylose, Mannose, Glucose, and Galactose, respectively (Figure 7b, table inset). A larger view of the graph is provided in Supplementary Figure S1. The molecular weight of the purified polysaccharide was calculated $(\mathrm{MN}$ : $4.5852 \mathrm{e} 3 \mathrm{~g} / \mathrm{mol}$, MW: $5.8659 \mathrm{e} 3 \mathrm{~g} / \mathrm{mol}$ ).

Finally, we tested the role of the purified polysaccharide F212 in cell proliferation. Incubation of F212 with mouse cell line RAW264.7 increased their proliferation (Figure 7c). However, at the concentrations used, the AR extract and the partially purified polysaccharides showed little effect on cell proliferation compared to the control.

\section{DISCUSSION}

We previously reported that the water extract of Amauroderma rude possessed the highest activity among thirteen different medicinal mushrooms tested in inducing cancer cell death [6]. It is believed that the polysaccharides isolated from medicinal mushrooms are the major components that possess anticancer activities [25-27]. In this study, we precipitated the polysaccharides from the water extract of Amauroderma rude using a high concentration of ethanol. After a series of chromatography purification, we obtained a single peak (F212) and identified the monosaccharide components of the polysaccharide.

Polysaccharides have been extensively isolated from many medicinal mushrooms and their functions have been studied showing anticancer properties [28-31]. The polysaccharide we purified represented the first polysaccharide from Amauroderma rude, and it showed to have strong functions in immunopotentiation in vitro and in vivo. We found that the crude extract was able to increase lymphocyte proliferation, increase natural killer cell activity, and increase macrophage metabolism and phagocytosis. Consistent with these effects, CD45 expression, production of $\mathrm{NO}$, and production of antibodies were also up-regulated. Our results were consistent with another mushroom, Ganoderma lucidum, whose isolated polysaccharides, small molecules, and total extract showed many of the same anticancer effects [32-37]. As a result of the strong immunoregulatory activity, we detected a significant inhibitory effect of Amauroderma rude on tumor growth. Moreover, the
Amauroderma rude extracts were injected in areas far away from the tumor implantation sites in the mice. Therefore, this suggests that Amauroderma rude caused the inhibitory effect on tumor growth by regulating the immune system.

We tested the hypothesis that Amauroderma rude could regulate the immune activity of the host by stimulating the production of cytokines. It has been reported that the polysaccharides can promote expression of tumor necrosis factor alpha $(\mathrm{TNF} \alpha)$ and interferon gamma (IFN $\gamma)$ [38]. TNF $\alpha$ is a cytokine involved in systemic inflammation, which is expressed mainly by activated macrophages, lymphocytes, and NK cells. $\mathrm{TNF} \alpha$ can promote an inflammatory response and exert an acute immune response [39, 40]. IFN $\gamma$ is a dimerized cytokine that is critical for innate and adaptive immunity against infections. It is an important activator of macrophages and can be secreted by NK cells and macrophages. Therefore it also has immunoregulatory and antitumor properties [41-43]. Our results showed that treatment with Amauroderma rude induced significant production of TNF $\alpha$ and IFN $\gamma$. This may represent the essential role of Amauroderma rude in the inhibition of tumor growth. In clinical studies, cancer patients in advanced stages were given polysaccharide fractions of Ganoderma lucidum orally three times a day for 12 weeks. This treatment resulted in a significant increase in the plasma concentrations of IL-2, IL-6, and IFN $\gamma$, and a significant increase in the mean NK cell activity compared to baseline [44]. Likewise, our in vitro and in vivo experiments showed that Amauroderma rude also stimulated the production of IL-2, TNF- $\alpha$ and IFN $\gamma$. IL-2 is a cytokine signaling molecule in the immune system where it regulates the activities of white blood cells (e.g. lymphocytes) that are responsible for the immunity [45]. Our results showed that the polysaccharides from Amauroderma rude may function similarly to those from Ganoderma lucidum, by producing these cytokines with potent effects on immunity and anticancer.

To test the effect of polysaccharides on regulating immune activity and inhibiting tumor growth, it is essential to perform the experiments in normal mice that have normal immune systems. In cancer research, most of the tumor growth experiments are conducted in nude mice using human cancer cell lines. Nude mice have deficient immune systems to begin with, and are not ideal animals to study drugs and herbal medicine which may possess immune-regulatory activity. Thus, a tumor cell line originally developed from the same strain of mice is essential to be able to form tumors in those mice.

Although we found that the F212 polysaccharide displayed immune regulatory activity, other molecules in the pool may also possess activity in immune regulation and antitumor growth. For example, when we used the chromatography approach to purify the bioactive ingredients, we could only use the fraction with the highest immune regulatory activity for further 
a

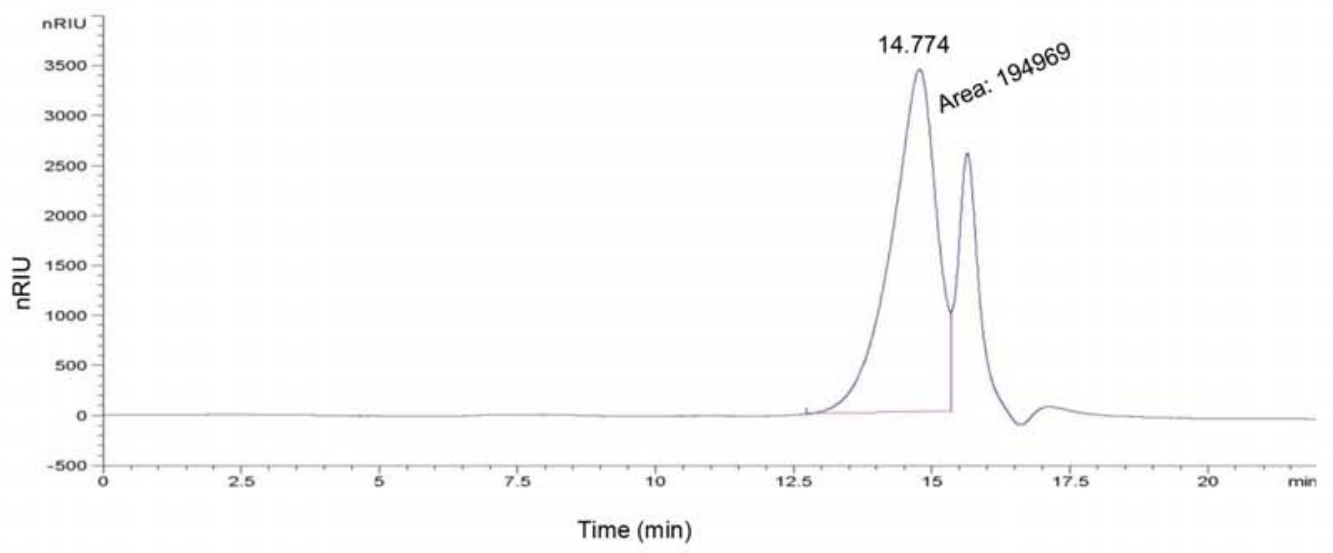

b
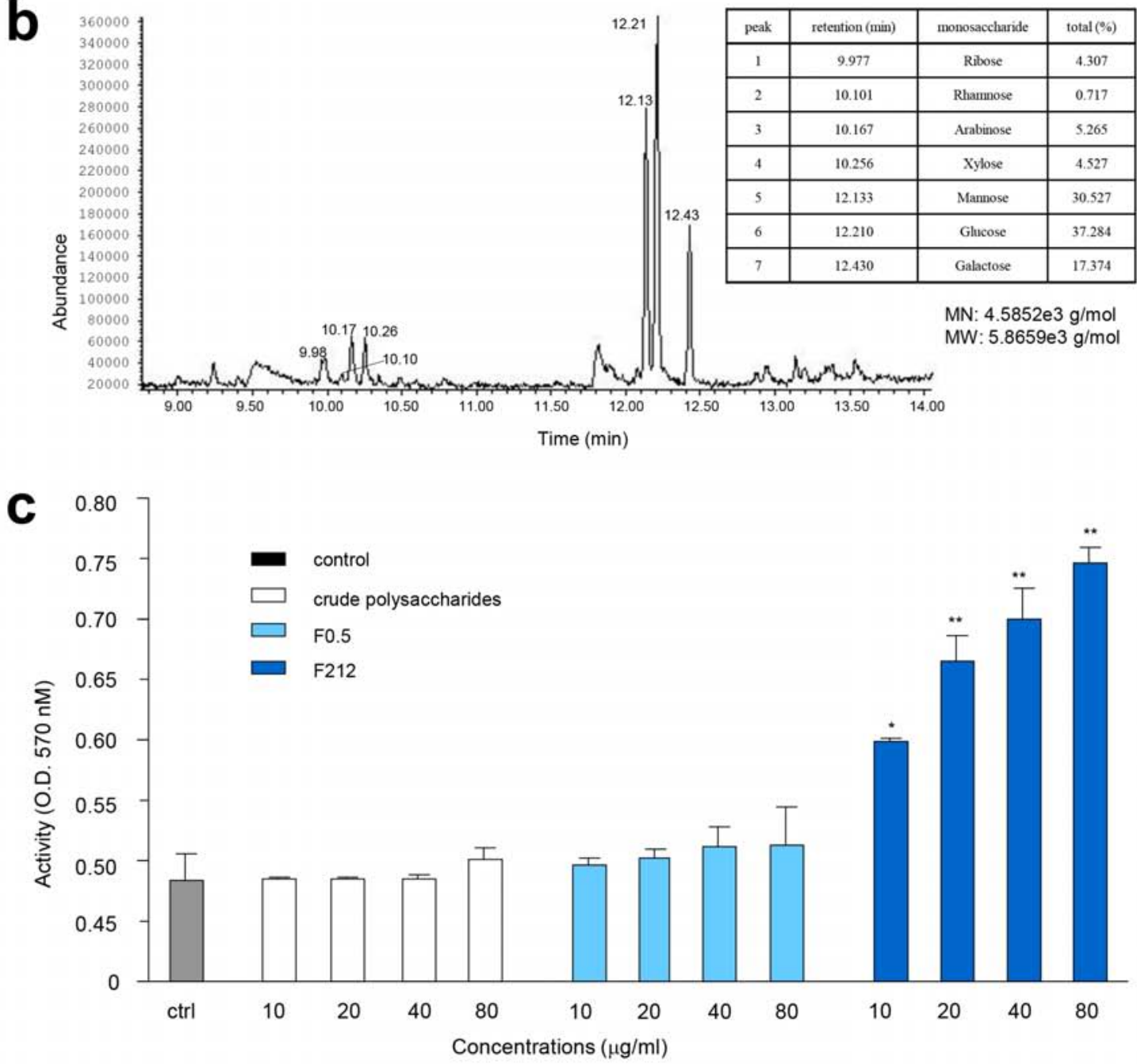

Figure 7: Purification of polysaccharides and their effects on cell proliferation GC-MS. a. Diagram showing two components (F211 and F212) after chromatography from F1 fraction using SephacrylTM S100 High Resolution. b. Identification of the molecular structure and composition of F212. The peaks were of polysaccharide characteristics, and are labeled with numbers. The table inset provides the names and composition of the monosaccharides. The molecular number and molecular weight of the purified polysaccharide are shown underneath the table. c. Incubation of the purified polysaccharide (F212) with mouse cell line RAW264.7 increased cell proliferation. At the concentrations used, the AR crude extract and the partially purified polysaccharides (F0.5) showed little effect on cell proliferation as compared with the control (ctrl). Asterisks indicate significant differences. ${ }^{*} p<0.05, * * p<0.01$. Error bars, $\operatorname{SD}(n=5)$. 
purification. This relied on the total activity of each fraction, rather than the activity of a single molecule. It is possible that one fraction may contain some molecules with very high immune regulatory activity, but still not be selected because the fraction contained fewer such molecules. Moreover, other fractions that were not selected could contain novel molecules with potent immune regulatory activity. This awaits further investigation.

In general, it is known that large molecules with complex structures possess strong capacities to induce immune responses. For example, large polysaccharides linking to a peptide, such as PSK and PSP purified from Coriolus versicolor $[14,15]$, and some complex polysaccharides purified from Ganoderma lucidum, have been found to have a strong effect on immunity. An unexpected result from our study was the identification of a relatively small polysaccharide F212 that also possessed strong immunity. The composition of F212 appeared similar to many polysaccharides purified from other medicinal mushrooms. The structure of F212 awaits future investigation.

In summary, we have purified and identified a small polysaccharide with strong immunity from a newly recognized medicinal mushroom, Amauroderma rude. This represents the first known polysaccharide of this species, which has strong anticancer activity [6]. It appears that polysaccharides from Amauroderma rude possess multiple effects on regulating the immune system at the molecular and cellular level. This may explain the strong immune function of the molecule. Understanding the structure and function of this molecule may provide helpful information in drug design.

\section{MATERIALS AND METHODS}

\section{Preparation of the aqueous extract from Amauroderma rude}

We extracted the aqueous fraction from Amauroderma rude fruit bodies which were supplied by Yuewei Edible Fungi Technology Co. Ltd and authenticated for utilization by the Center for Research and Development of Edible Fungi, Guangdong Institute of Microbiology.

Dry Amauroderma rude fruit bodies (200 g) were crushed and extracted with 30 -folds of water at $80^{\circ} \mathrm{C}$ for $2 \mathrm{~h}$. After centrifugation (6000 rpm, $30 \mathrm{~min}$ ), the supernatants were collected and the precipitation was extracted another two times. All supernatants were concentrated to 1 liter and precipitated with 3 volumes of $95 \%$ ethanol overnight, followed by centrifugation (6000 rpm, $30 \mathrm{~min}$ ). The residue ethanol and water was removed at $50^{\circ} \mathrm{C}$. The yield of crude polysaccharide fraction (AR) was $2.1 \%$ of the fresh weight.

\section{Purification of crude polysaccharides}

Column fractionation was the process used to purify the biologically active ingredient of AR. AR was suspended with distilled water. In the meantime, $750 \mathrm{ml}$ DEAE Sepharose Fast Flow was packed into a column of $15 \times 70 \mathrm{~cm}(\mathrm{~d} \times \mathrm{h})$.

The AR suspension was applied to the top of the Sepharose gel bed. After twenty min of careful application of the sample, the column was eluted with four bed volumes of $0.1,0.5,1.0$, and $2.0 \mathrm{~mol}$ of $\mathrm{NaCl}$ at an elution speed of $20 \mathrm{ml} / \mathrm{min}$. Each collection contained $1500 \mathrm{ml}$. Every collection was concentrated and lyophilised producing fractions $\mathrm{F}_{0.1}, \mathrm{~F}_{0.5}, \mathrm{~F}_{1}$, and $\mathrm{F}_{2}$. The immunomodulatory activity was screened by proliferation of mouse spleen lymphocytes.

\section{Proliferation and CD45 expression of mouse lymphocytes from spleen}

Male BALB/c mice (5-week old, 18 to $20 \mathrm{~g}$ ) were purchased from Guangdong Medical Laboratory Animal Center (Foushan City, China). The license number was SCXK2008-0002. The health certificate number was 44007200005061. The animals were provided with water and mouse chow ad libitum, and were housed in a rodent facility at $22 \pm 1{ }^{\circ} \mathrm{C}$ with a $12 \mathrm{~h}$ light-dark cycle for acclimatization. All procedures involving animals and their care were approved by the Ethics Committee of the Guangdong Laboratory Animals Monitoring Institute. Our previous results proved the LD50/( $\mathrm{mg} / \mathrm{kg})$ of AR was above and beyond $15000 \mathrm{mg} / \mathrm{kg}$ and AR was regarded as nontoxic.

The mice were sacrificed by dislocating cervical vertebrae and marinated in $75 \%$ ethanol for three min. The spleen was excised from the mice in sterile environment and rinsed with serum-free RPMI-1640 medium twice, then grinded and passed through a 100-mesh sieve. The suspended lymphocytes were pelleted by centrifugation (1000 rpm, $5 \mathrm{~min}$ ), resuspended in Tris- $\mathrm{NH}_{4} \mathrm{Cl}$ and pelleted by centrifugation (1000 rpm, $5 \mathrm{~min}$ ) to remove red blood cells. This step was repeated once and the cells were resuspended in serum-free RPMI-1640 to wash one more time. After being pelleted by centrifugation (1000 rpm, $5 \mathrm{~min}$ ), the cells were resuspended in RPMI1640 medium and the number of cells were counted. The cells $\left(5 \times 10^{6}\right.$ cells $\left./ \mathrm{ml}\right)$ were seeded on 96 -well tissue culture plates in RPMI-1640 containing 10\% FBS. The plates were incubated at $37^{\circ} \mathrm{C}$ for $2 \mathrm{~h}$. Drugs and samples were added to the cultures at the concentrations indicated in each figure. The cultures were subject to MTT assay after incubating at $37^{\circ} \mathrm{C}$ for $44 \mathrm{~h}$.

For measurement of CD45 production, the lymphocytes were divided into five groups: control, ConA $(5 \mu \mathrm{g} / \mathrm{ml})$, AR-100 (5 $\mu \mathrm{g} / \mathrm{ml})$, AR-200 (5 $\mu \mathrm{g} / \mathrm{ml})$, and AR-300 $(5 \mu \mathrm{g} / \mathrm{ml})$. Cells $\left(5 \times 10^{6}\right.$ cells $\left./ \mathrm{ml}\right)$ were 
seeded on 24-well tissue culture plates in RPMI-1640 containing $10 \% \mathrm{FBS}$. The plates were incubated at $37^{\circ} \mathrm{C}$ for $2 \mathrm{~h}$, followed by addition of drugs and samples. The cultures were then incubated at $37^{\circ} \mathrm{C}$ for $48 \mathrm{~h}$ before flow cytometry analysis for CD45 expression. The procedure was performed as described [46].

\section{Assays using mouse peritoneal macrophages}

Male BALB/c mice (5-week old, 18 to $20 \mathrm{~g}$ ) were sacrificed by dislocating cervical vertebrae and marinated in $75 \%$ ethanol for three min. Serum-free RPMI- 1640 medium was injected into the peritoneal cavity and withdrawn to collect the ascites. After centrifugation (1000 rpm, $5 \mathrm{~min}$ ), cells in the pellets were suspended in RPMI-1640 and the number of cells were counted. Cells $\left(5 \times 10^{6}\right.$ cells $\left./ \mathrm{ml}\right)$ were seeded on 96 -well tissue culture plates in RPMI-1640 containing 10\% FBS.

In energy metabolism assay, the plates were incubated at $37^{\circ} \mathrm{C}$ for $2 \mathrm{~h}$. Drugs and samples were added to the cultures at the concentrations indicated in each figure. The cultures were then incubated at $37^{\circ} \mathrm{C}$ for $20 \mathrm{~h}$ followed by a MTT assay.

In the neutral red engulfment assay, cells in the 96-well plates were incubated at $37^{\circ} \mathrm{C}$ for $24 \mathrm{~h}$. After centrifugation (1800 rpm, $5 \mathrm{~min}$ ), $100 \mu \mathrm{l}$ of neutral red in physiological saline solution $(0.1 \%)$ were added to each well. The plates were incubated at $37^{\circ} \mathrm{C}$ for $30 \mathrm{~min}$. After centrifugation (1800 rpm, $5 \mathrm{~min}$ ), each well was washed with $200 \mu$ PBS twice, followed by addition of $100 \mu \mathrm{l}$ cytolysate (acetic acid:anhydrous alcohol = 50:50). The cells were incubated at room temperature overnight followed by MTT assay.

To measure the nitric oxide concentrations, the plates were incubated at $37^{\circ} \mathrm{C}$ for $2 \mathrm{~h}$. Drugs and samples were added to the culture at the concentrations indicated in each figure. The cultures were measured after incubating at $37^{\circ} \mathrm{C}$ for $48 \mathrm{~h}$ by Griess assay.

\section{Assay using natural killer (NK) cells}

In NK cell assay, the harvested mixture in the lymphocytes was suspended in Tris- $\mathrm{NH}_{4} \mathrm{Cl}$ and centrifuged (1000 rpm, $5 \mathrm{~min}$ ), repeated twice. The pellets were then suspended in serum-free RPMI-1640 and centrifuged (1000 rpm, $5 \mathrm{~min}$ ). The pellets were resuspended with RPMI-1640 and the number of cells were counted. Cells $\left(5 \times 10^{6}\right.$ cells $\left./ \mathrm{ml}\right)$ were seeded on 96 -well tissue culture plates in RPMI-1640 supplemented with 10\% FBS. The plates were incubated at $37^{\circ} \mathrm{C}$ for $2 \mathrm{~h}$. Drugs and samples were added to the cultures. The effect of the NK cells was assayed after incubating at $37^{\circ} \mathrm{C}$ for $24 \mathrm{~h}$ as follows: human breast cancer cells MT- $1\left(1 \times 10^{8}\right.$ cells $\left./ \mathrm{ml}\right)$ were used as target cells and incubated with three groups of NK cells: group I: $100 \mu \mathrm{l} \mathrm{NK}$ cells mixed with $100 \mu \mathrm{l}$ MT-1 cells, group II: $100 \mu \mathrm{l}$ NK cells mixed with $100 \mu \mathrm{l}$ RPMI1640, and group III: $100 \mu \mathrm{MT}-1$ cells mixed with $100 \mu \mathrm{l}$ RPMI-1640. The plates were incubated at $37^{\circ} \mathrm{C}$ for $20 \mathrm{~h}$ followed by MTT assay.

\section{Effect of AR on macrophages in vivo}

For energy metabolism assay, male BALB/c mice (5-week old, 18 to $20 \mathrm{~g}$ ) were divided into two groups. One group of mice was lumbar injected with $200 \mu \mathrm{l} \mathrm{AR}$ ( $4 \mathrm{mg} / \mathrm{ml}$ ), and the other group served as a control. $24 \mathrm{~h}$ after the injection, proliferation of peritoneal macrophages was measured by MTT assay as described earlier.

In phagocytic index assay, the function of the macrophages was assessed via a carbon clearance test. Each mouse was intravenously injected with diluted India ink at $100 \mu \mathrm{l} / 10 \mathrm{~g}$ body weight. Blood specimens were collected at $2 \mathrm{~min}(\mathrm{t} 1)$ and $10 \mathrm{~min}(\mathrm{t} 2)$ from the retinal venous plexuses, and $20 \mu \mathrm{l}$ blood was then mixed with $2 \mathrm{ml} 0.1 \% \mathrm{Na}_{2} \mathrm{CO}_{3}$. The absorbance at $600 \mathrm{~nm}$ was measured on a UV-visible spectrophotometer with $0.1 \%$ $\mathrm{Na}_{2} \mathrm{CO}_{3}$ as the blank. The liver and the spleen were weighed, and the phagocytic index was calculated as follows:

$\mathrm{K}=(\lg \mathrm{OD} 1-\lg \mathrm{OD} 2) /(\mathrm{t} 2-\mathrm{t} 1)$, where OD1 was for $\mathrm{t} 1$ and OD2 was for $\mathrm{t} 2$.

Phagocytic index ${ }_{c}=\sqrt[3]{\kappa} \times \mathrm{A} /(\mathrm{B}+\mathrm{C})$, where $\mathrm{A}$ is the body weight, $\mathrm{B}$ is the liver weight, and $\mathrm{C}$ is the spleen weight.

\section{Effect of AR on the immunoregulation in vivo}

Female BALB/c mice (5 week old, 18 to $20 \mathrm{~g}$ ) were randomly divided into 4 groups (12 mice each). The mice were given the crude polysaccharides orally $(0.2 \mathrm{ml} /$ mouse, low dose, $19 \mathrm{mg} / \mathrm{ml}$, medium dose, $38 \mathrm{mg} / \mathrm{ml}$, and high dose, $114 \mathrm{mg} / \mathrm{ml}$ ) every two days for a total of 30 days. The negative control group contained water alone. The positive control group was lumbar injection with LPS, every other day for five times totally $(0.1 \mathrm{ml}$ for the first time and $0.2 \mathrm{ml}$ each for the following 4 times, $0.05 \mathrm{mg} / \mathrm{ml})$.

The mice were subject to visceral organ weight measurements. $24 \mathrm{~h}$ after the last drug administration, the animals were weighed and then sacrificed via decapitation. The spleen and thymus were excised. The spleen, thymus, and body weight of every group were measured. Organ index $(\mathrm{mg} / \mathrm{g})=($ weight of thymus or spleen $) /$ body weight.

For lymphocyte proliferation assay, the spleens were excised sterilely from the mice $24 \mathrm{~h}$ after the last drug administration. Lymphocytes were prepared at a density of $5 \times 10^{7}$ cells $/ \mathrm{ml}$. Cells $\left(5 \times 10^{7}\right.$ cells $\left./ \mathrm{ml}\right)$ were seeded on 96-well tissue culture plates in RPMI-1640 containing $10 \% \mathrm{FBS}$. The plates were incubated at $37^{\circ} \mathrm{C}$ for $2 \mathrm{~h}$. Drugs or the AR product were added to the cultures at 
the concentrations indicated in the figure. The cultures were then measured after incubating at $37^{\circ} \mathrm{C}$ for $72 \mathrm{~h}$ by MTT assay.

For Delayed hypersensitivity (DH) (auricle swelling model) assay, the abdomen was shaved and covered with $50 \mu \mathrm{l}$ DNFB $24 \mathrm{~h}$ after the last drug administration. The right ear was covered with $10 \mu$ l DNFB 5 days later. After $24 \mathrm{~h}$, the mice were sacrificed by dislocating cervical vertebrae and the earlaps were cut. The earlaps with a diameter $8 \mathrm{~mm}$ were weighted.

For antibody production assay, the mice were injected in the lumbar with $0.2 \mathrm{ml}$ sheep erythrocyte suspension (2\%) $24 \mathrm{~h}$ after the last drug administration. Five days later, the spleen was taken sterilely from the mice and used to prepare a cell suspension $\left(5 \times 10^{6}-1 \times 10^{7}\right.$ cells $/ \mathrm{ml})$. The activity of the antibody was tested in 6-well plates, which were pre-coated with $0.5 \%$ agarose gel $(1 \mathrm{ml} /$ well) dissolved in PBS. The spleen cell suspension $(200 \mu \mathrm{l})$ was mixed with sheep erythrocyte suspension $(50 \mu \mathrm{l}, 20 \%)$ and $0.5 \mathrm{ml}$ agarose gel $(0.5 \%$ dissolved in Hank's buffer and pre-warmed to $46-50^{\circ} \mathrm{C}$ ), followed by immediate addition to the agarose gel-coated 6 -well plates. The plates were incubated at $37^{\circ} \mathrm{C}$ for $1 \mathrm{~h}$, followed by addition of $500 \mu \mathrm{l}$ complement (1:10 dilutions). After incubation at $37^{\circ} \mathrm{C}$ for $2 \mathrm{~h}$, hemolysis plaques were counted. Hemolysis plaque $=$ plaque $/ 10^{6}$ spleen cells.

For Delayed Type Hypersensitivity assay, the mice were lumbar injected with $0.2 \mathrm{ml}$ sheep erythrocyte suspension (2\%) $24 \mathrm{~h}$ after the last drug administration. Five days later, serum was harvested by centrifugation. The serum was doubling diluted and added into Microhemagglutination Test Board (100 $\mu \mathrm{l} /$ well), followed by addition of sheep erythrocyte suspension cells $(0.5 \%$, $100 \mu \mathrm{l} /$ well). The board was incubated at $37^{\circ} \mathrm{C}$ for $3 \mathrm{~h}$. Antibody agglutination was examined and calculated as follows: Aggregate $=(\mathrm{S} 1+2 \mathrm{~S} 2+3 \mathrm{~S} 3 \ldots \ldots \mathrm{nSn})$, in which $1,2,3 \ldots \ldots n$ represented dilution factors and $\mathrm{S}$ means the degree of agglutination.

To test engulfment of Fluorescent Microsphere, the mice were lumbar injected with $0.2 \mathrm{ml}$ suspension of sheep erythrocyte (2\%), $24 \mathrm{~h}$ after the last drug administration. Ascites were harvested by injecting $3 \mathrm{ml}$ Hank's (serum containing medium) into the peritoneal cavity. Cell number was adjusted to $4-6 \times 10^{5} \mathrm{cells} / \mathrm{ml}$. The cells $(1 \mathrm{ml})$ were added to the 6 -well tissue culture plates, to which Fluorescent Microspheres $\left(1 \times 10^{7}\right.$ cells/plate $)$ had been added. The plates were incubated at $37^{\circ} \mathrm{C}$ for $2 \mathrm{~h}$. The supernatant was removed and $0.3 \mathrm{ml} \mathrm{PBS}\left(4^{\circ} \mathrm{C}\right)$ was added. The cells were suspended and separated from the free Fluorescent Microspheres by passing through a 200-mesh sieve. Engulfment of Fluorescent Microspheres by the cells was detected by flow cytometry. The Engulf percentage (\%) and Engulf index were calculated as follows:

Phagocyticpercentage $(\%)=$ macrophage $($ Engulf Fluorescent Microsphere)/macrophage(total)
Phagocytic index = Fluorescent Microsphere engulfed/macrophage (total)

\section{Effect of AR on tumor growth}

Tumor growth assay was performed as described [47, 48]. Briefly, female BALB/c mice (5 week old, 18 to $20 \mathrm{~g}$ ) were randomly divided into 3 groups (12 mice each). 4T1 cells $\left(2 \times 10^{5}\right.$ cells in $\left.100 \mu \mathrm{l}\right)$ were injected into each mouse. The third day after cell implantation, the mice were lumbar injected with drugs or test samples $(0.2 \mathrm{ml} /$ mouse $)$ every three days for a total of ten injections. The test samples were either 2.4 $\mathrm{mg} /$ mouse (Group I), or $4.8 \mathrm{mg} / \mathrm{mouse}$ (Group II). The negative control was serum-free RPMI-1640 medium. Tumor growth was monitored twice per week. All of the mice were sacrificed by cervical dislocation and tumors were harvested on day 15 . When the animal experiment finished, the body weight and tumor weight was measured.

The partially purified polysaccharides $\left(\mathrm{F}_{0.5}\right)$ were also used to evaluate its effect on tumor growth in the same approach. Tumor growth was monitored every 5 days. The body weight was measured at the beginning and end of the experiment. The tumor sections were examined by immunohistochemical staining and expression of IL-2, TNF- $\alpha$ and IFN- $\gamma$ were examined by ELISA test.

\section{Statistical analysis}

The results of all the experiments were subject to statistical analysis by $t$-test. The levels of significance was set at $p<0.05(*)$ and $p<0.01(* *)$ respectively.

\section{ACKNOWLEDGMENTS}

The authors thank Dr. Ren Huang (Guangdong Laboratory Animals Monitoring Institute) and Xiaolan Huang (China National Analytical Center) for their technical assistance. This work was supported by grants from the Introduction of Leading Talent Project of Guangdong Province, 2013BAD16B05, 2010B080100068, 2010B050600007, and 2012B090600050.

\section{Abbreviations}

DMEM, Dulbecco's modified Eagle's medium; FBS, fetal bovine serum; PAGE, polyacrylamide gel electrophoresis; IL-2, Interleukin 2; TNF $\alpha$, tumor necrosis factor alpha; IFN $\gamma$, interferon gamma;

\section{REFERENCE}

1. Horng CT, Huang JK, Wang HY, Huang CC, Chen FA. Antioxidant and antifatigue activities of Polygonatum 
Alte-lobatum Hayata rhizomes in rats. Nutrients. 2014; 6:5327-5337.

2. Smiderle FR, Baggio $\mathrm{CH}$, Borato DG, SantanaFilho AP, Sassaki GL, Iacomini M, Van Griensven LJ. Anti-inflammatory properties of the medicinal mushroom Cordyceps militaris might be related to its linear (1->3)-beta-D-glucan. PLoS One. 2014; 9:e110266.

3. Vo TS, Ngo DH, Kang KH, Jung WK, Kim SK. The beneficial properties of marine polysaccharides in alleviation of allergic responses. Mol Nutr Food Res. 2015; 59:129-138.

4. Hung JS, Huang J, Lin YC, Huang MJ, Lee PH, Lai HS, Liang JT, Huang MC. C1GALT1 overexpression promotes the invasive behavior of colon cancer cells through modifying O-glycosylation of FGFR2. Oncotarget. 2014; 5:2096-2106.

5. Hsu HY, Lin TY, Wu YC, Tsao SM, Hwang PA, Shih YW, Hsu J. Fucoidan inhibition of lung cancer in vivo and in vitro: role of the Smurf2-dependent ubiquitin proteasome pathway in TGFbeta receptor degradation. Oncotarget. 2014; 5:7870-7885.

6. Jiao C, Xie YZ, Yang X, Li H, Li XM, Pan HH, Cai MH, Zhong HM, Yang BB. Anticancer activity of Amauroderma rude. PLoS One. 2013; 8:e66504.

7. Huang HY, Korivi M, Yang HT, Huang CC, Chaing YY, Tsai YC. Effect of Pleurotus tuber-regium polysaccharides supplementation on the progression of diabetes complications in obese-diabetic rats. Chin J Physiol. 2014; 57:198-208.

8. Lu WJ, Chang NC, Jayakumar T, Liao JC, Lin MJ, Wang SH, Chou DS, Thomas PA, Sheu JR. Ex vivo and in vivo studies of CME-1, a novel polysaccharide purified from the mycelia of Cordyceps sinensis that inhibits human platelet activation by activating adenylate cyclase/cyclic AMP. Thromb Res. 2014; 134:1301-1310.

9. Pan HH, Yu XT, Li T, Wu HL, Jiao CW, Cai MH, Li XM, Xie YZ, Wang Y, Peng T. Aqueous extract from a Chaga medicinal mushroom, Inonotus obliquus (higher Basidiomycetes), prevents herpes simplex virus entry through inhibition of viral-induced membrane fusion. Int $\mathrm{J}$ Med Mushrooms. 2013; 15:29-38.

10. Wesa KM, Cunningham-Rundles S, Klimek VM, Vertosick E, Coleton MI, Yeung KS, Lin H, Nimer S, Cassileth BR. Maitake mushroom extract in myelodysplastic syndromes (MDS): a phase II study. Cancer Immunol Immunother. 2015; 64:237-247.

11. Besednova NN, Zaporozhets TS, Kuznetsova TA, Kryzhanovskii SP, Kovalev NN, Zviagintseva TN. [Hepatoprotective effects of extracts and polysaccharides from seaweed]. Antibiot Khimioter. 2014; 59:30-37.

12. $\mathrm{Xu} \mathrm{Z}$, Shan Y. Anti-fatigue effects of polysaccharides extracted from Portulaca oleracea L. in mice. Indian J Biochem Biophys. 2014; 51:321-325.

13. Djordjevic B, Skugor S, Jorgensen SM, Overland M, Mydland LT, Krasnov A. Modulation of splenic immune responses to bacterial lipopolysaccharide in rainbow trout (Oncorhynchus mykiss) fed lentinan, a beta-glucan from mushroom Lentinula edodes. Fish Shellfish Immunol. 2009; 26:201-209.

14. Newman DJ, Cragg GM. Natural products as sources of new drugs over the last 25 years. J Nat Prod. 2007; 70:461-477.

15. Hayakawa K, Mitsuhashi N, Saito Y, Takahashi M, Katano S, Shiojima K, Furuta M, Niibe H. Effect of krestin (PSK) as adjuvant treatment on the prognosis after radical radiotherapy in patients with non-small cell lung cancer. Anticancer Res. 1993; 13:1815-1820.

16. Huang SQ, Ning ZX. Extraction of polysaccharide from Ganoderma lucidum and its immune enhancement activity. Int J Biol Macromol. 2010; 47:336-341.

17. Jung BG, Lee JA, Lee BJ. Immunoprophylactic effects of shiitake mushroom (Lentinula edodes) against Bordetella bronchiseptica in mice. J Microbiol. 2012; 50:1003-1008.

18. Forland DT, Johnson E, Tryggestad AM, Lyberg T, Hetland G. An extract based on the medicinal mushroom Agaricus blazei Murill stimulates monocyte-derived dendritic cells to cytokine and chemokine production in vitro. Cytokine. 2010; 49:245-250.

19. Chen CJ, Vijaya Krishna R, Tsai CC, Wu WH, Chao LK, Hwang KH, Chien CM, Chang HY, Chen ST. Structure and functions of gamma-dodecalactone isolated from Antrodia camphorata for NK cell activation. Bioorg Med Chem. 2010; 18:6896-6904.

20. Adachi Y, Okazaki M, Ohno N, Yadomae T. Enhancement of cytokine production by macrophages stimulated with $(1 \longrightarrow 3)$-beta-D-glucan, grifolan (GRN), isolated from Grifola frondosa. Biol Pharm Bull. 1994; 17:1554-1560.

21. Kirk PM CP, Minter DW, Stalpers JA. Dictionary of the Fungi (Wallingford: CSIRO PUBLISHING).

22. Schepetkin IA, Quinn MT. Botanical polysaccharides: macrophage immunomodulation and therapeutic potential. Int Immunopharmacol. 2006; 6:317-333.

23. Crouse J, Xu HC, Lang PA, Oxenius A. NK cells regulating $\mathrm{T}$ cell responses: mechanisms and outcome. Trends Immunol. 2015; 36:49-58.

24. Schorn T, Drago F, Tettamanti G, Valvassori R, de Eguileor M, Vizioli J, Grimaldi A. Homolog of allograft inflammatory factor-1 induces macrophage migration during innate immune response in leech. Cell Tissue Res. 2015; 359:853-864.

25. Lu H, Uesaka T, Katoh O, Kyo E, Watanabe H. Prevention of the development of preneoplastic lesions, aberrant crypt foci, by a water-soluble extract from cultured medium of Ganoderma lucidum (Rei-shi) mycelia in male F344 rats. Oncol Rep. 2001; 8:1341-1345.

26. Lu H, Kyo E, Uesaka T, Katoh O, Watanabe H. Prevention of development of N, N'-dimethylhydrazine-induced colon tumors by a water-soluble extract from cultured medium of 
Ganoderma lucidum (Rei-shi) mycelia in male ICR mice. Int J Mol Med. 2002; 9:113-117.

27. Lu H, Kyo E, Uesaka T, Katoh O, Watanabe H. A watersoluble extract from cultured medium of Ganoderma lucidum (Rei-shi) mycelia suppresses azoxymethaneinduction of colon cancers in male F344 rats. Oncol Rep. $2003 ; 10: 375-379$.

28. Wu QP XY, Li SZ, La Pierre DP, Deng Z, Chen Q, Li C, Zhang Z, Guo J, Wong CKA, Lee DY, Yee A, Yang BB. Tumour cell adhesion and integrin expression affected by Ganoderma lucidum. Enzyme \& Microbial Technol. 2006; 40:32-41.

29. Liao SF, Liang CH, Ho MY, Hsu TL, Tsai TI, Hsieh YS, Tsai CM, Li ST, Cheng YY, Tsao SM, Lin TY, Lin ZY, Yang WB, Ren CT, Lin KI, Khoo KH, et al. Immunization of fucose-containing polysaccharides from Reishi mushroom induces antibodies to tumor-associated Globo H-series epitopes. Proc Natl Acad Sci U S A. 2013; 110:13809-13814.

30. Wu DT, Meng LZ, Wang LY, Lv GP, Cheong KL, Hu DJ, Guan J, Zhao J, Li SP. Chain conformation and immunomodulatory activity of a hyperbranched polysaccharide from Cordyceps sinensis. Carbohydr Polym. 2014; 110:405-414.

31. Cui J, Chisti Y. Polysaccharopeptides of Coriolus versicolor: physiological activity, uses, and production. Biotechnol Adv. 2003; 21:109-122.

32. LaPierre DP, Lee DY, Li SZ, Xie YZ, Zhong L, Sheng W, Deng Z, Yang BB. The ability of versican to simultaneously cause apoptotic resistance and sensitivity. Cancer Res. 2007; 67:4742-4750.

33. Wu QP, Xie YZ, Deng Z, Li XM, Yang W, Jiao CW, Fang L, Li SZ, Pan HH, Yee AJ, Lee DY, Li C, Zhang Z, Guo J, Yang BB. Ergosterol peroxide isolated from Ganoderma lucidum abolishes microRNA miR378-mediated tumor cells on chemoresistance. PLoS One. 2012; 7:e44579.

34. Zhao S, Ye G, Fu G, Cheng JX, Yang BB, Peng C. Ganoderma lucidum exerts anti-tumor effects on ovarian cancer cells and enhances their sensitivity to cisplatin. Int $\mathbf{J}$ Oncol. 2011; 38:1319-1327.

35. Xie YZ LS, Yee A, La Pierre DP, Deng Z, Lee DY, Wu QP, Chen Q, Li C, Zhang Z, Guo J, Jiang Z, Yang BB. Ganoderma lucidum inhibits tumour cell proliferation and induces tumour cell death. Enzyme \& Microbial Technol. 2006; 40:177-185.

36. Hsu MJ, Lee SS, Lee ST, Lin WW. Signaling mechanisms of enhanced neutrophil phagocytosis and chemotaxis by the polysaccharide purified from Ganoderma lucidum. Br J Pharmacol. 2003; 139:289-298.

37. Bao XF, Wang XS, Dong Q, Fang JN, Li XY. Structural features of immunologically active polysaccharides from Ganoderma lucidum. Phytochemistry. 2002; 59:175-181.

38. Zhang Q, Lin Z. [Study on antitumor activity and mechanism of Ganoderma polysaccharides B]. Zhongguo Zhong Xi Yi Jie He Za Zhi. 1999; 19:544-547.

39. Chimenti MS, Tucci P, Candi E, Perricone R, Melino G, Willis AE. Metabolic profiling of human CD4+ cells following treatment with methotrexate and anti-TNF-alpha infliximab. Cell Cycle. 2013; 12:3025-3036.

40. Rushworth SA, Zaitseva L, Langa S, Bowles KM, MacEwan DJ. FLIP regulation of HO-1 and TNF signalling in human acute myeloid leukemia provides a unique secondary anti-apoptotic mechanism. Oncotarget. 2010; 1:359-366.

41. Schroder K, Hertzog PJ, Ravasi T, Hume DA. Interferongamma: an overview of signals, mechanisms and functions. J Leukoc Biol. 2004; 75:163-189.

42. Shchors K, Yehiely F, Deiss LP. Cell Death Inhibiting RNA (CDIR) modulates IFN-gamma-stimulated sensitization to Fas/CD95/Apo-1 and TRAIL/Apo-2L-induced apoptosis. Cell Cycle. 2004; 3:1606-1611.

43. Fang W, Zhang J, Hong S, Zhan J, Chen N, Qin T, Tang Y, Zhang Y, Kang S, Zhou T, Wu X, Liang W, Hu Z, Ma Y, Zhao Y, Tian Y, et al. EBV-driven LMP1 and IFN-gamma up-regulate PD-L1 in nasopharyngeal carcinoma: Implications for oncotargeted therapy. Oncotarget. 2014; 5:12189-12202.

44. Gao Y, Zhou S, Jiang W, Huang M, Dai X. Effects of ganopoly (a Ganoderma lucidum polysaccharide extract) on the immune functions in advanced-stage cancer patients. Immunol Invest. 2003; 32:201-215.

45. Lam E, Pareek TK, Letterio JJ. Cdk5 controls IL-2 Gene Expression via Repression of the mSin3a-HDAC Complex. Cell Cycle. 2015; 14:1327-36.

46. Li H, Gupta S, Du WW, Yang BB. MicroRNA-17 inhibits tumor growth by stimulating T-cell mediated host immune response. Oncoscience. 2014; 1:531-539.

47. Fang L, Li H, Wang L, Hu J, Jin T, Wang J, Yang BB. MicroRNA-17-5p promotes chemotherapeutic drug resistance and tumour metastasis of colorectal cancer by repressing PTEN expression. Oncotarget. 2014; 5:2974-2987.

48. Siragam V, Rutnam ZJ, Yang W, Fang L, Luo L, Yang X, Li M, Deng Z, Qian J, Peng C, Yang BB. MicroRNA miR98 inhibits tumor angiogenesis and invasion by targeting activin receptor-like kinase-4 and matrix metalloproteinase-11. Oncotarget. 2012; 3:1370-1385. 